Shanan Jurnal Pendidikan Agama Kristen Vol. 1 No. 22017 | 21

\title{
KAJIAN SOTERIOLOGI DALAM TEOLOGI UNIVERSALISME, CALVINISME, DAN ARMINIANISME SERTA KAITANNYA DENGAN PEMBELAJARAN PENDIDIKAN AGAMA KRISTEN
}

\author{
Demsy Jura \\ Universitas Kristen Indonesia \\ Program Studi Magister Pendidikan Agama Kristen \\ demsy.jura@uki.ac.id
}

\begin{abstract}
abstrak
Soteriologi adalah konsep penting dalam kajian teologi Kristen. Istilah ini berasal dari

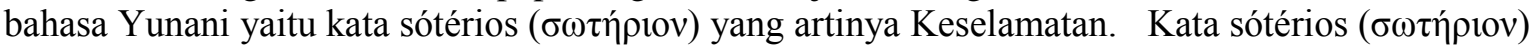
ini berasal dari dua kata yaitu: sótér $(\sigma \omega \tau \eta ́ \rho)$ yang berarti Penyelamat dan logia $(\lambda o ́ \gamma 1 \alpha)$ adalah Perkataan. Dengan demikian maka dalam segi etimologi, kata Soteriologi berarti ajaran tentang keselamatan manusia.

Berdasarkan kajian hermeneutika, ada beberapa teori yang berkaitan dengan soteriologi. ikut memberi warna dalam kajian teologi tentang doktrin keselamatan ini. Walaupun doktrin Soteriologi Kristen terdiri atas beberapa kelompok dengan tekanan keyakinannya masing-masing, namun kesemuanya itu tidak mengabaikan peran Yesus Kristus sebagai juruselamat umat manusia.

Kelompok Universalisme Kristen yang percaya bahwa keselamatan itu bersifat universal; artinya pada akhirnya semua orang diselamatkan. Kelompok Calvinisme yang menekankan aspek Kedaulatan Allah, sangat tegas menyatakan bahwa Yesus Kristus adalah juruselamat dunia; dan melaluiNya, setiap orang yang terpilih sejak masa kekekalan itu akan diselamatkan karena iman dan kepercayaannya akan Tuhan Yesus Kristus, dan kaum Armenianisme dengan tekanan Kehendak Bebas, dimana aspek manusia dipandang menentukan keselamatannya namun jalannya tetap ada didalam Yesus Kristus. Kelompok Armenianisme percaya bahwa manusia berkehendak bebas dan itu asalnya dari Tuhan, dan dalam kehendak bebas itulah maka seseorang terselamatkan karena ia percaya kepada Kristus. Walaupun memiliki teori dan tekanan yang berbeda dalam argumentasi soteriologi-nya, yaitu bahwa Yesus Kristus adalah Tuhan dan Juruselamat umat manusia.

Soteriologi Kristen yang muncul sebagai bagian dari hasil kajian hermeneutika para ahli teologi itu, sesungguhnya mampu memperkaya nuansa teologi seseorang, termasuk para guru yang terlibat dalam pembelajaran Pendidikan Agama Kristen (PAK). Studi teologi Soteriologi yang beragam tersebut tidaklah perlu dipermasalahkan sebab intissari dari Soteriologi Kristen tidak digugat sama sekali. Keselamatan hanya ada dalam diri Yesus Kristus merupakan keputusan bersama dan final. Itulah sebabnya, pembelajaran Pendidikan Agama Kristen harus tetap berjalan sebagaimana mestinya. Ajaran bahwa keselamatan hanya melalui Yesus Kristus menjadi pokok dalam studi Soteriologi dan hal itu wajib dijabarkan dalam pembelajaran Pendidikan Agama Kristen.
\end{abstract}

Kata Kunci: Arminianisme, Calvinisme, Pendidikan Agama Kristen, Soteriologi, Teologi, Universalisme 


\section{Pendahuluan}

Salah satu masalah yang mendasar dalam kehidupan umat manusia adalah dosa (Rm. 3:23; 6:23), dan hanya didalam Kristus Yesus-lah maka manusia bisa memperoleh keselamatan dengan penebusan yang dikerjakanNya melalui Kayu Salib (Rm. 5:8). Keselamatan disediakan sebagai anugerah dari Allah yang adil, yang memberikan kasih karunia-Nya kepada manusia yang telah jatuh ke dalam dosa (2 Kor. 5:18; Rm. 5:11; Kol. 1:20). Manusia yang penuh dosa itu diangkat menjadi keluarga-Nya (Gal. 4:5; Ef. 1:13; 2 Kor. 1:22), dengan menjadikannya ciptaan yang baru. Selanjutnya Roh Kudus memampukan dia untuk berjalan dalam kehidupan yang baru, sambil terus mematikan perbuatan-perbuatan daging (Rom.8:13), dan akhirnya ia dijadikan sama dengan Kristus (Rom.8:29) dan keselamatan-nya digenapi dalam kemuliaan (Fil. 3:21). Rasul Paulus menyatakan bahwa Kitab Suci dapat memberikan Hikmat dan menuntun kepada keselamatan oleh iman kepada Yesus Kristus (2 Timotius 3:15), dan menyediakan saranasarana yang penting untuk menikmati keselamatan yang penuh rahmat itu (Rom. 3:19; Gal. 2:16).

Soteriologi merupakan salah satu tema penting dalam doktrin Kristen. Doktrin yang membicarakan hal keselamatan bagi umat manusia yang hanya diperoleh melalui Yesus Kristus itu sangat beragam. Itulah sebabnya muncul berbagai macam penafsiran atas doktrin keselamatan ini. Masing-masing pihak yang berkepentingan didalamnya berupaya memberikan penjelasan yang menurutnya cukup baik, alkitabiah dan masuk akal.

Walaupun penjelasan Soteriologi Kristen hingga saat ini dalam beberapa pendapat teologis, seperti Soteriologi Universalisme, Soteriologi Calvinisme dan Soteriologi Armenianisme; namun dari bagian demi bagian yang dibicarakan sesungguhnya hal tersebut bertumpu pada persoalan hermeneutika. Dengan berbagai sudut pandang, maka suatu hal dalam Alkitab telah ditafsirkan berdasarkan apa yang diyakini oleh seseorang melalui pendekatan hermeneutika. Dengan melakukan suatu pendekatan hermeneutika tertentu akan menggunakan hal tersebut dalam berbagai kegiatan penafsiran Alkitab yang mereka lakukan.

Dengan berbagai pola dan metode yang dipergunakan dalam melakukan tafsir atas suatu kajian dalam Alkitab; terkadang hal Soteriologi Kristen memberikan hasil penafsiran yang berbeda dengan penafsiran Soteriologi lainnya. Hal ini berlaku umum pada kajian bidang teologi lainnya, seperti: Eklesiologi, Bibliologi, Anthropologi, Eskatologi dan sebagainya. Akibatnya, doktrin Soteriolog Kristen tampil dengan warna teologi masing-masing.

Studi Soteriologi yang berkembang dari waktu ke waktu, seiring dengan pergumulan para ahli teologi; telah memberikan masukan yang berarti dalam kajian teologi Kristen. Dalam studi Soteriologi, kajian Soteriologi dari kelompok Calvinisme dan Armenianisme menjadi fokus dalam penelitian ini. Hal tersebut dianggap penting karena keduanya memiliki argumenasi sendiri-sendiri dalam membangun teorinya dan hal inilah yang akan dibahas dalam penelitian ini. Selain itu, hubungan keyakinan Soteriologi Calvinisme dan Soteriologi Armenianisme dikaitkan dengan pembelajaran Pendidikan Agama Kristen (PAK) diharapkan akan memberi warna dalam studi Pendidikan Agama Kristen.

\section{Beberapa Pengertian}

Apakah Soteriologi itu? Perlu diketahui bahwa sesungguhnya, istilah Soteriologi merupakan istilah umum dalam dunia teologi. Istilah ini berasal dari bahasa Yunani yaitu kata sótérios ( $\sigma \omega \tau \eta ́ p ı v)$ yang artinya Keselamatan. Kata sótérios

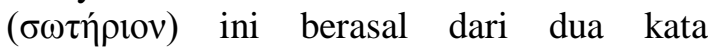
yaitu: sótér ( $\sigma \omega \tau \eta ́ \rho)$ yang berarti Penyelamat dan logia $(\lambda o ́ \gamma 1 \alpha)$ adalah Perkataan. Dengan demikian maka dalam segi etimologi, kata Soteriologi berarti ajaran tentang ke- 
selamatan manusia. ${ }^{1}$ Alan Richardson dalam buku yang berjudul An Introduction To The Theology Of The New Testament mengatakan bahwa: Keselamatan yang diperoleh manusia itu berasal dari Tuhan Allah. Keselamatan dari Allah telah diwujudkan dalam sejarah kehidupan, dan bagi orang yang percaya keselamatan akan dinyatakan pada hari terakhir. Penghakiman dan keselamatan yang akan dinyatakan oleh kebenaran itu pada masa terlahir sebenarnya sudah diterima dalam kehidupan, kematian dan kebangkitan Yesus. Itu sebabnya setiap orang yang percaya pada Kristus dibenarkan oleh Allah. ${ }^{2}$ Keselamatan dalam Kristen merupakan kasih karunia Tuhan (Ef. 2:8-9), dan hanya diperoleh melalui Yesus Kristus (Yoh. 3:16, 14:1-3). Walaupun ada banyak teori tentang soteriologi Kristen, namun kesemuanya mengacu kepada Yesus Kristus sebagai satu-satunya Tuhan dan juruselamat umat manusia.

Walaupun keselamatan itu merupakan pemberian Allah secara cuma-cuma, namun orang-orang yang percaya kepada Kristus patut menunjukkan pola kehidupan yang baik dan berkenan. Hal tersebut sebagai pembuktian diri dalam menjalani kehidupan Kristen yang bertanggung jawab. Perlunya setiap orang percaya dijalani dengan baik dan bertanggung jawab oleh setiap orang yang percaya kepadaNya.

Soteriologi Universalisme Keyakinan Universalisme adalah doktrin yang percaya bahwa semua manusia; tanpa memandang agama mereka, pada akhirnya akan diselamatkan. Paham ini diyakini oleh Gereja Universalisme di Amerika Serikat. Universalisme merupakan suatu pengajaran ada di hampir dengan semua agama yang ada, yaitu: suatu ajaran yang mempercayai bahwa semua manusia yang pernah hidup di dunia ini akan diselamatkan dan masuk ke

\footnotetext{
${ }^{1}$ Bandingkan pengertian Soteriologi sebagaimana yang disampaikan Henk ten Napel dalam Kamus Teologi Inggris-Indonesia, (Jakarta: BPK Gunung Mulia, 2011), 295.

${ }^{2}$ Alan Richardson, An Introduction To The

Theology Of The New Testament, (London: SCM Press LTD, London 1972), 80, 82.
}

dalam kerajaan sorga, apakah ia baik atau jahat semuanya akan ada di sorga karena Allah sangat mengasihi dunia dan orangorang berdosa. Universalisme adalah suatu doktrin yang mengajarkan bahwa pada akhirnya semua orang akan selamat, dan hal tersebut terjadi karena kasih karunia Tuhan atas seluruh umat manusia.

Jika memperhatikan pengertian tersebut di atas, maka secara tidak langsung, beberapa orang telah masuk dalam kelompok universalisme Kristen, diantaranya Hans Kung, Karl Rahner, Raimundo Panikkar, dan dari Indonesia adalah Victor I. Tanja dan sebagainya. Mereka mengakui bahwa, keselamatan hanya dapat diperoleh melalui Yesus Kristus tetapi dengan catatan bahwa Yesus Kristus itupun juga dapat hadir di luar tembok kekristenan. Sehingga sangatlah tidak bijak untuk membicarakan masalah hidup kekal dengan membedakan surga dan neraka. Alasan yang paling mendasar adalah karena Kristus itu kasih adanya sehingga tidaklah mungkin ada neraka atau tempat penghukuman yang kekal. ${ }^{3}$

Soteriologi Calvinisme. Salah satu pokok penting dalam bahasan Soteriologi Kristen adalah ajaran Calvinisme yang hingga saat ini masih banyak pengikutnya. Kelompok ini sangat aktif berdiskusi dengan berbagai argumentasi historis dan teologis; ketika membahas isu-isu Soteriologi Kristen. Francois Wendel dalam buku Calvin, mengatakan: Calvinisme berbicara tentang mengenal Allah Alkitab dan hidup Coram Deo yaitu hidup di hadapan wajah Allah. Calvinisme sesungguhnya merupakan sinonim untuk biblikalisme sistematis. Hanya Calvinisme yang memimpin kepada Kekristenan Alkitabiah yang sejati. Allah yang berdaulat adalah sentral dalam teologia Calvin. ${ }^{4}$ Jadi Wendel melihat Calvinisme sebagai sebuah ajaran yang biblikal dan sistematis sehingga mampu memimpin umat Kristen kepada pengertian teologi yang benar dimana Allah berdaulat atasnya.

\footnotetext{
${ }^{3}$ B. Kuyper, For Whom Did Christ Die? (Grand Rapids: Baker Book House, 1959), 13-14.

${ }^{4}$ Francois Wendel, Calvin, (Surabaya: Momentum,2010), 81.
} 
Selain menyampaikan tema sentral tentang Kedaulatan Allah dalam warna teologinya, kaum Calvinisme juga menyampaikan pokok pemikiran Soteriologi yang tersusun dalam persidangan khusus untuk itu. Rangkuman teologi Calvinisme itu dikenal dengan istilah TULIP, dimana hal ini muncul sebagai reaksi atas kaum Arminianisme yang mempertanyakan doktrin keselamatan yang pada saat itu sangat populer dibicarakan.

Soteriologi Armenianisme diperkenalkan oleh seorang yang bernama Jacobus Arminius (1560-1609); seorang teolog Belanda dengan tegas menolak pengajaran Calvinisme mengenai doktrin tersebut. Pemikiran kedaulatan Allah menjadi warna Calvinisme tidak diterima. Jacobus Arminius yang ketika itu menjabat sebagai profesor theologi di Leiden university dan juga gembala sidang gereja Dutch Reformed; berjuang untuk memodifikasi ajaran John Calvin tersebut. Arminius juga menentang ajaran teolog Belanda, Franciscus Gomarus (1563-1641) dan pengganti John Calvin, yaitu Theodore Beza (1519-1605).

Jacobus Arminius berbeda pendapat dengan pemahaman teologi yang diyakini kaum Calvinisme, khususnya tentang Predistinasi. Ia juga berusaha untuk memodifikasi Calvinisme sehingga Allah tidak dapat dianggap sebagai perancang, juga manusia sebagai robot ditangan Allah. Arminius yang pernah belajar belajar teologi di Universitas Leiden dengan para guru yang luar biasa, yaitu: Lambertus Danaeus (15301595), Johannes Drusius (1550 -1616), Guillaume Feuguereius, dan Johann Kolmann, yang merupakan theolog ternama pada waktu itu. Arminius juga sempat belajar di bawah bimbingan seorang teolog terkemuka lainnya yaitu Theodore Beza di Jenewa tahun 1582, yang dikemudian hari ia berbeda pendapat dengan Beza.

Johann Kolmann yang merupakan salah seorang guru Jacobus Arminius yang memiliki keyakinan dan mengajarkan kepada para muridnya bahwa Calvinisme membuat Tuhan menjadi pribadi tiran dan algojo. Itulah sebabnya di bawah pengaruh para gurunya itu, Arminius belajar dengan baik dan memiliki bibit teologi yang akan berkembang menjadi suatu teologi yang kemudian akan bersaing dengan teologi Reformed dari Yohanes Calvin. Kolmann dianggap salah satu pribadi yang memberikan kontribusi dalam kehidupan berteologi dari Armenius.

Para pengikut awal pengajaran Arminius di Belanda dikenal sebagai Remonstrants setelah mereka menerbitkan dokumen berisi lima poin ketidaksepakatan dengan Calvinisme klasik, berjudul Remonstrantice (1610). Pemikiran Armenius terus bergulir dan memperoleh tempat dihati warga yang kala itu sangat didominasi oleh pemikiran John Calvin yang berusaha dan mereka berupaya melakukan penolakan terhadap pemikiran Predestinasi Calvinis terhadap ajaran Dirk Volckertszoon Koornhert (1522-1590).

\section{Pembelajaran Pendidikan Agama Kristen (PAK)}

Istilah bahasa Yunani paidagōgia $(\pi \alpha 1 \delta \alpha \gamma \omega \gamma i \alpha)$ menunjuk pada pengertian pendidikan, dan kata Pendidikan itu sendiri berasal dari kata Education (bah. Inggris), Educare (bah. Latin), dengan pengertian Mengeluarkan dan Menuntun atau Membimbing. Istilah ini mengandung arti; suatu tindakan untuk membimbing keluar. Kata Pandegogik (bah. Yunani) yang berarti Ilmu menuntun anak; dan Dildung (bah. Jerman) yang mengandung arti membangkitkan kekuatan terpendam dan meng-aktifkan kekuatan atau potensi anak. $^{5}$

Dalam Ensiklopedi Pendidikan, secara umum pendidikan dapat diartikan sebagai, semua perbuatan dan usaha dari generasi tua untuk mengalihkan pengetahuan, pengalaman, kecakapan, serta keterampilannya kepada generasi muda sebagai usaha mempersiapkan mereka agar dapat memenuhi fungsi hidupnya, baik jasmaniah maupun

\footnotetext{
${ }^{5}$ B. Samuel Sijabat, Strategi Pendidikan Kristen (Yogyakarta: Andi Offset, 1944), 5.
} 
rohaniah. Penegasan itu menyatakan bahwa pendidikan merupakan usaha upaya sadar tujuan, atau bersahaja sehingga menuntut perencanaan, strategi atau pendekatan. ${ }^{6}$

Pendidikan Agama Kristen merupakan sarana yang dipakai Tuhn untuk memperlengkapi setiap individu melalui serangkaian pembelajaran untuk meningkat-kan pengetahuan dan juga perilaku yang bernafaskan iman Kristen. Paulus Lilik Kristanto dengan mengutip pendapat Warner C. Graedorf mengatakan bahwa Pendidikan Agama Kristen adalah: Proses pengajaran dan pembelajaran yang berdasarkan Alkitab, berpusat pada Kristus, dan bergantung kepada Roh Kudus, yang membimbing setiap pribadi pada semua tingkat pertumbuhan melalui pengajaran masa kini ke arah pengenalan dan pengalaman rencana dan kehendak Allah melalui Kristus dalam setiap aspek kehidupan, dan melengkapi mereka bagi pelayanan yang efektif, yang berpusat pada Kristus sang Guru Agung dan perintah yang mendewasakan pada murid.,"7

Pendidikan Agama Kristen itu sendiri sesunggguhnya berpangkal pada persekutuan umat Tuhan. Dalam perjanjian lama pada hakekatnya dasar-dasar terdapat pada sejarah suci purbakala, bahwa Pendidikan Agama Kristen itu mulai sejak terpanggilnya Abraham menjadi nenek moyang umat pilihan Tuhan, bahkan bertumpu pada Allah sendiri karena Allah menjadi peserta didik bagi umat-Nya."

Gereja dipanggil melalui Pendidikan Agama Kristen untuk menolong orang dewasa menemukan Allah yang aktif dalam setiap peristiwa kehidupan, mempercayakan hidup mereka dalam tarafnya yang paling dalam untuk alasan ini, dan untuk merayakan dengan sukacita perbuatan Allah yang sempurna dalam Kristus dan berlangsung

\footnotetext{
${ }^{6}$ Ibid. hlm. 8.

${ }^{7}$ Paulus Lilik Kristanto, Prinsip dan Praktek PAK Penuntun bagi Mahasiswa Teologi dan PAK, Pelayan Gereja, Guru Agama dan keluarga Kristen, (Yogyakarta : Andi Offset ), 4. ${ }^{8}$ E.G.Homrighausen, Pendidikan Agama Kristen, (Jakarta: BPK Gunung Mulia, 1985), 112.
}

terus melalui Roh Kudus. ${ }^{9}$ Pendidikan Agama Kristen merupakan pendidikan yang berisi ajaran-ajaran kekristenan dengan menekankan ketiga aspek pendidikan yaitu pengetahuan (kognitif), sikap dan nilai-nilai (afektif), dan keterampilan (psikomotor) yang berdasarkan iman Kristen. Pengertian ini lebih menekankan pada pengajaran kepada anak didik atau umat. ${ }^{10}$ Pendidikan Kristen bersumber dari Alkitab dan melihat Tuhan Yesus Kristus sebagai pribadi yang sentral dalam setiap kegiatan Pendidikan Agama Kristen.

Pembelajaran merupakan suatu sistem karena dalam pembelajaran semua unsur saling berkaitan. Antara unsur yang satu dengan yang lainnya saling berkaitan untuk mencapai tujuan dari pembelajaran itu sendiri. Unsur-unsur yang saling terkait antara lain; siswa, guru, bahan ajar, kurikulum, dan sebagainya. Pembelajaran adalah suatu sistem karena, di dalamnya terdapat interaksi. Interaksi ini mencakup komponen-komponen yang saling berkaitan dan tidak dapat terpisahkan, antara lain siswa, guru, sumber belajar, materi dan yang lainnya. Semua unsur tersebut mempunyai hubungan fungsional yang berinteraksi secara dinamis untuk mencapai tujuan, yaitu keberhasilan pendidikan.

Pembelajaran dilakukan dengan tujuan untuk membantu menfasilitasi proses belajar. Dalam proses tersebut, seseorang akan terlibat dalam sistem pengajaran yang terdiri atas: Siswa, Guru dan Tenaga pendukung lainnya atau tenaga kependidikan. Selanjutnya dalam suatu proses pembelajaran, ada juga material yang meliputi: Bukubuku, Papan Tulis, dan Side, Film dan sebagainya, yang digunakan untuk menunjang keberhasilan proses pembelajaran. Fasilitas dan perlengkapan lainnya, seperti: Ruang Kelas, juga termasuk didalamnya.

\footnotetext{
${ }^{9}$ William F. Case, "Adult Education in the Chuch". Marvin J. Taylor, penyunting. An Introduction to Christian Education, (Nashville, New York: Abingdon Press, 1966), 205. ${ }^{10}$ Hardi Budiyana, Dasar-dasar Pendidikan Agama Kristen. (Solo: Berita Hidup Seminary. 2011), 4.
} 
Pembelajaran disebut suatu sistem karena dalam pembelajaran semua unsur saling berkaitan. Pembelajaran PAK dipahami sebagai sebuah proses belajar yang terkait satu unsur dengan yang lainnya; namun dalam koridor Pendidikan Kristen.

\section{Soteriologi Kristen dalam Pembelajaran Pendidikan Agama Kristen (PAK)}

Maksud dari Soteriologi Kristen dalam pembelajaran PAK bermaksud membicarakan tentang doktrin Soteriologi dalam proses dan unsur pembelajaran PAK. Doktrin Soteriologi masuk dalam kurikulum, meresapi dalam keyakinan iman peserta didik dan juga para pendidik serta bahkan semua unsur penunjang di dalamnya. Itulah sebabnya hal tersebut menjadi sesuatu yang sangat penting, yaitu ketika doktrin soteriologi Kristen masuk dalam sistem pembelajaran PAK, dan itu akan berdampak luar bagi siswa, guru dan bahkan semua pribadi yang ada dalam sistem pembejalaran yang dimaksud.

Harianto GP mengutip pendapat Witherington, yang mengatakan bahwa mengajar bukan hanya menuangkan materi pelajaran ke dalam pikiran atau menyampaikan kebudayaan bangsa kepada anak-anak. Theaching is primarely and always the stimulation of the learning Pendidikan adalah hal yang paling utama dan selalu menjadi pendorong dalam pembelajaran, jadi, murid yang sudah mendapat dorongan dari guru tidak akan berhenti belajar, tetapi terus menyelidiki dan memperdalam pengetahuannya. ${ }^{11}$ Pengajar atau pendidik yang efektif selalu mengajar dari limpahan hidupnya yang penuh. Guru mengelola dan memotivasi anak didiknya supaya aktif belajar sehingga mengalami perubahan atau mencapai tujuan yang diharapkan. ${ }^{12}$

\footnotetext{
${ }^{11}$ Harianto GP, Pendidikan Agama Kristen dalam Alkitab \& Dunia Pendidikan Masa Kini (Yogyakarta: Andi Offset, 2012), 14.

${ }^{12}$ B.S. Sidjabat, Mengajar secara Profesional (Bandung: Kalam Hidup, 2009), 30.
}

Alkitab Perjanjian Lama mengungkapkan bahwa kata Ajaran atau Pengajar berasal dari kata Ibrani Yarah (ירָ) yang biasanya diterjemahkan sebagai: Mengajar, Memberitahukan, Melatih, Meletakan, Melepaskan, Menunjukan, Meng-hujani (lih. Kejadian 46:28, Keluaran 4:12, Ulangan 24:8). Kata lainnya adalah Lamad (לָָָ dengan terjemahan Melatih dengan rajin, Belajar, Cekatan, Mengajar, Pengajar, Pengajaran (Ul. 5:1, Maz. 119:7; Yer. 12:16; I Taw.

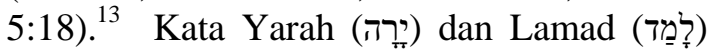
menunjuk kepada pengertian yang sama, yaitu bahwa pengajar adalah seorang yang menunjuk dengan jari, mengatur, memberitahu, melatih, membidik seperti pemanah, dan mengajarkan jalan-jalan Tuhan. Pengajaran menyebabkan orang lain belajar dan seperti galah untuk menghalau, sebuah tongkat, yang menyebabkan umat Allah berjalan di jalan-jalan Tuhan (Ul. 32:1-2; Yes. 55:10-11). ${ }^{14}$ Demikian juga kata rabi dan rabuni telah ikut mewarnai kajian tentang pendidikan dalam Perjanjian Lama.

Alkitab Perjanjian Baru menyampaikan data bahwa ajaran atau pengajar berasal

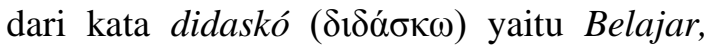
Mengajar. Jika mengkaji kata didaktikós ( $\delta 1 \delta \alpha \kappa \tau \imath \kappa o ́ \varsigma)$ yang berarti cakap mengajar, merupakan sebuah penjelasan yang bukan sekedar mengajar, melainkan memiliki kecakapan yang khusus berkaitan dengan kegiatan pembelajaran. Itulah sebabnya kata didaktik menunjuk kepada Ilmu mengajar yang bukan asal mengajar. Didaktik adalah ilmu mengajarkan sesuatu cara yang cepat dan tepat sehingga murid dapat memahami dan menanggapinya; dalam arti: mempraktekan. Mengajar adalah unsur utama dalam mendidik. Akar kata yang sama dalam Perjanjian Baru berkaitan dengan mengajar, terlihat beberapa perkataan yang menunjuk seputar hal mengajar, seperti didaktos yangitu pengajar, didaskalos, dengan arti pengajar, dan didaskalia yang berarti pengajaran.

\footnotetext{
${ }^{13}$ Kevin J. Jemaat dalam Perjanjian Baru (Malang: Gandum Mas, 2004), 406..

${ }^{14}$ Ibid, 407.
} 


\section{Kajian Soteriologi dan Kaitannya Dengan Pembelajaran Pendidikan Agama Kristen (PAK)}

Dalam beberapa kelompok Kristen telah muncul berbagai penafsiran teologi Kristen dimana mereka saling membedakan satu kelompok dengan kelompok yang lain. Itulah sebabnya walaupun doktrin keselamatan dalam Kristen terlihat sudah baku karena Yesus Kristus menjadi pusat atas kajian yang dimaksud, namun beberapa hal didalamnya telah mengundang multi-tafsir.

Dengan demikian maka tak terpungkiri lagi bahwa dalam soteriologi Kristen telah nampak beberapa aliran. Berkaitan dengan hal tersebut, Chris Marantika dalam buku Doktrin Keselamatan dan Kehidupan Rohani mengungkapkan bahwa: Doktrin keselamatan adalah suatu doktrin yang sederhana, tetapi juga kompleks. Namun inilah suatu doktrin yang perlu dimengerti secara tepat karena suatu anathema atau kutuk diletakkan diatas siapapun juga termasuk malaikat-malaikat dan hamba-hamba Allah yang mengkhotbahkan Injil yang lain dari Injil yang sebenarnya dan tidak berusaha menjelaskannya dengan setepat-tepatnya pula (Galatia 1:8). ${ }^{15}$ Pernyataan Marantika tersebut diatas memberikan suatu pembuktian bahwa doktrin Soteriologi sangat penting dan menjadi dasar bagi setiap kepercayaan dan doktrin Kristen.

Teolog Amerika Serikat, Charles C. Ryrie, dalam buku Teologi Dasar 2, menegaskan bahwa: Soteriologi, ajaran tentang keselamatan, harus merupakan pokok bahasan yang paling luas dalam Alkitab. Masalah itu mencakup seluruh waktu, baik kekekalan di masa lalu maupun kelak. Dengan suatu cara manapun keselamatan berhubungan dengan seluruh umat manusia. Tanpa kekecualian. Cabang-cabangnya bahkan sampai dunia malaikat. Keselamatan merupakan tema dalam Perjanjian Lama dan Perjanjian baru. Keselamatan bersifat perorangan, nasional dan dunia semesta. Keselamatan itu berpusat pada pribadi yang

\footnotetext{
${ }^{15}$ Chris Marantika, Doktrin Keselamatan dan Kehidupan Rohani, (Yogyakarta: Iman Press, 2002), 1.
}

paling besar, yaitu Tuhan kita Yesus Kristus. ${ }^{16}$ Bagi Ryrie, pentingnya mempelajari doktrin Soteriologi Kristen, bukan semata-mata pada aspek pengetahuan belaka, melainkan ciri dari Soteriologi itu sendiri. Dengan mempelajarinya, diharapkan seseorang akan memiliki pengetahuan yang memadai dalam doktrin tersebut.

Doktrin keselamatan dalam ajaran Kristen merupakan sesuatu hal yang penting karena kekristenan bukan hanya berbicara mengenai hidup masa kini namun juga berkaitan dengan kehidupan masa datang. Orang percaya memperoleh keyakinan untuk hidup kekal dimasa yang akan datang (Yoh. 14:1-3, 6; Kis. 4:12; Yoh. 1:13; 1 Yoh. 5:1013; 2 Kor. 5:10). Itulah sebabnya bukanlah suatu kebetulan ketika seseorang diselamatkan, melainkan suatu proses ilahi yang telah lama direncanakan Allah karena kejatuhan manusia dalam dosa merupakan suatu fakta yang tak bisa disangkali.

Soteriologi merupakan doktrin penting dalam kekristenan karena hal tersebut berkaitan langsung dengan kebutuhan yang paling hakiki dalam diri setiap orang yang percaya kepada Kristus. Kekristenan membicarakan konsep keselamatan sebagai hal yang penting karena pribadi Kristus menjadi sentral atas doktrin ini. Soteriologi Kristen memberikan jaminan keselamatan kepada umat yang percaya.

Berkaitan dengan soteriologi, kekristenan menunjuk Alkitab sebagai sumber informasi yang akurat mengenai aspek tersebut. Alkitab menyatakan bahwa semua orang telah berbuat dosa dan telah kehilangan kemuliaan Allah, dan membawa akibat dosa pada keadaan yang mengerikan, yaitu maut. (Rom. 3:23; 6:23). Ini merupakan kenyataan sejarah yang membuktikan akan keberdosaan manusia. Walaupun be-berapa orang tidak dapat menerima kenyataan keberdosannya, namun fakta ke-berdosaan manusia bukanlah sesuatu yang mengada-ada.

\footnotetext{
${ }^{16}$ Charles C. Ryrie, Teologi Dasar 2, (Yogyakarta: Penerbit Andi Offset, 1991), 15.
} 
Konsep Maria immaculata ${ }^{17}$, muncul dikalangan gereja Katolik, dimana keyakinan ini secara langsung membantah fakta keberdosaan umat manusia sebagaimana yang diuraikan diatas. Keyakinan gereja Katolik tentang Immaculata Conceptio atau dikandung tanpa noda merupakan doktrin gereja Katolik Roma secara turun-temurun yang meyakini bahwa bahwa Maria dikandung tanpa noda dosa apapun. Keyakinan ini didasarkan bahwa bayi yang dikandungnya itu adalah kudus, dan Allah menjaga Maria, ibu Yesus dari segala kehilangan kekudusan yang merundung umat manusia, dan sebaliknya ibu Yesus ini dipenuhi dengan rahmat yang luar biasa. Umat

${ }^{17}$ Doktrin gereja Katolik mengenai Maria Immaculata mulai diajarkan oleh Paus Pius IX, yang diumumkan pada tanggal 8 Desember 1854; dimana dengan berani ia menyatakan bahwa Maria, ibu Yesus, dikandung tanpa noda dosa asal. Keyakinan ini semakin diperkuat ketika terjadi sebuah penampakan Maria di Lourdes, Grotto Massabielle, Perancis; dan terjadi selama 18 kali kepada Bernadete Soubirous, seorang gadis desa yang pada waktu itu masih berumur 14 tahun. Menurut keyakinan yang berkembang dimasyarakat pada waktu itu, Bunda Maria menyatakan dirinya sebagai, Perawan yang dikandung tanpa noda dosa atau the Immaculate Conception. Pernyataan tersebut oleh umat Katolik dianggap mengkonfirmasi ajaran Paus Pius IX dan menjadi bukti infailibilitas ajaran Paus tersebut. Dalam pengumumannya itu, Paus Pius IX menyatakan: Dengan inspirasi Roh Kudus, untuk kemuliaan Allah Tritunggal, untuk penghormatan kepada Bunda Perawan Maria, untuk meninggikan iman Katolik dan kelanjutan agama Katolik, dengan kuasa dari Yesus Kristus Tuhan kita, dan Rasul Petrus dan Paulus, dan dengan kuasa kami sendiri: "Kami menyatakan, mengumumkan dan mendefinisikan bahwa doktrin yang mengajarkan bahwa Bunda Maria yang terberkati, seketika pada saat pertama ia terbentuk sebagai janin, oleh rahmat yang istimewa dan satu-satunya yang diberikan oleh Tuhan yang Maha Besar, oleh karena jasa-jasa Kristus Penyelamat manusia, dibebaskan dari semua noda dosa asal, adalah doktrin yang dinyatakan oleh Tuhan dan karenanya harus diimani dengan teguh dan terus-menerus oleh semua umat beriman." (Dikutip dari Katolisitias.org, edisi 24 Juni 2008).
Katolik sangat percaya bahwa Maria kemudian menjalani kehidupannya yang tanpa dosa, dan tentunya hal tersebut telah masuk dalam pokok pengajaran gereja Katolik.

Sesungguhnya Soteriologi telah memberikan banyak perngaruh bagi gereja dari masa kemasa. Hal ini dapat terlihat dari pembahasan dan diskusi yang diselenggarakan gereja; telah memasukkan hal Soteriologi sebagai salah satu tema penting dalam kehidupan gereja. Pengaruh yang negatif sangat terlihat ketika gereja kurang memahami doktrin ini dengan baik. Chris Marantika mengatakan: Konsep keselamatan (soteriologi) juga mempunyai peranan sangat penting dalam dinamika pertumbuhan gereja. Bahkan kekeliruan dan kekabruan tentang dasar ini akan membuat gereja sebagai lembaga yang kehilangan arah. Sebagai akibatnya, gereja berputar-putar dalam lingkaran tak berujung pangkal. Ia akhirnya terjebak dalam tradisi Israel yang hidup bagi berkat dan tak peduli dengan tugas yang diembannya. ${ }^{18}$

Dapatlah dibayangkan jika gereja sebagai badan yang sangat berkepentingan bagi pertumbuhan iman umat Kristen; tidak mampu memberikan informasi yang baik, benar dan bertanggung jawab, mengenai doktrin Soteriologi.

Doktrin Soteriologi Kristen, atau hal yang membicarakan mengenai keselamatan dalam agama Kristen, merupakan salah isu sentral dari banyak diskusi teologi dari masa ke masa. Doktrin ini merupakan salah satu doktrin penting dalam kajian teologi sistematika. Berbagai pemikiran teologi, khususnya dalam kajian soteriologi terus berkembang dan bahkan cenderung dalam berbagai pandangan yang saling memperdebatkan satu dengan lainnya. Penekanan dari satu sisi dengan sisi lainnya terus disampaikan sehingga menimbulkan berbagai isu internal. Akibatnya diskusi teologi terus bergulir hingga sekarang ini. Teolog Wayne Grudem, dalam buku Systematic Theology:

\footnotetext{
${ }^{18}$ Chris Marantika, Doktrin Keselamatan dan Kehidupan Rohani, 5.
} 
An Introduction to a Biblical Doctrine, mengatakan bahwa: Ada tiga kriteria untuk menentukan Doktrin: 1). Doktrin itu sangat ditekankan dalam Kitab Suci. 2). Doktrin itu sangat penting dan berpengaruh dalam Ajaran Gereja sepanjang masa. 3). Doktrin itu sangat berpengaruh bagi pengajaran gereja sepanjang masa. Karena kesesuaiannya dengan situasi kontemporer (perubahan), doktrin-doktrin itu lebih diterima pada hari ini, ketimbang buku-buku teks Teologi Sistematika. ${ }^{19}$

Dengan memperhatikan uraian tersebut diatas, maka seseorang akan sangat terbantu dalam upaya pembahasan mengenai teologi. Dan untuk hal itulah maka pengetahuan teologi akan diperolehnya dengan baik. Yakub B. Susabda, dengan mengutip pendapat James Fowler, mengatakan bahwa: Di tengah kepusparagaman pandangan teologi, selalu muncul pergumulan iman untuk menemukan atau memperjelas identitasnya sendiri. Pertanggung-jawaban iman ini merupakan bagian integral dari suatu proses pertumbuhan rohani yang pada setiap fasesnya menuntut manifestasi iman yang berbeda-beda." 20 Jadi keragaman dalam berteologi sesunguhnya memberi dampak yang cukup baik, yaitu suatu identitas atau warna dari teolog itu sendiri.

Walaupun menggunakan sumber yang sama, yaitu Alkitab, namun haruslah diakui bahwa penggunaan metode hermeneutika dalam setiap kajian biblikal tidak dapat menghindarkan diri dari munculnya berbagai interpretasi atas suatu nats atau isu biblikal. Walaupun dengan sumber yang sama, namun karena pola yang berbeda atau tidak sama satu dengan lainnya; khususnya dalam hal penafsiran maka seringkali dijumpai beberapa perbedaan. Richard E. Palmer, dalam buku Interpratation Theory in Schleirmacher, Dilthey, Heidegger, and

\footnotetext{
${ }^{19}$ Wayne Grudem, Systematic Theology: An Introduction to a Biblical Doctrine, (Grand Rapid, Michigan: Zondervan Pub. House, 1994), 25-26.

${ }^{20}$ Yakub B. Susabda, Teologi Modern I, (Surabaya: Lembaga Reformed Injili Indonesia, 1993), 1.
}

Gadamer, menyatakan bahwa: Kata hermeneutika, secara etimologi berasal dari istilah Yunani, dari kata kerja hermeneuein, yang berarti menafsirkan, dan kata benda hermeneia dengan arti interpretasi. ${ }^{21}$ Palmer melanjutkan bahwa: Dari asal kata itu berarti ada dua perbuatan; menafsirkan dan hasilnya, penafsiran (interpretasi), seperti halnya kata kerja memukul dan menghasilkan pukulan. Kata Yunani hermeios mengacu pada seorang bijak, Delphic. Kata hermeios dan kata kerja yang lebih umum hermeneuein dan kata benda hermeneia diasosiasikan pada Dewa Hermes, dari sanalah kata itu berasal. ${ }^{22}$ Kajian Soteriologi yang baik sangat bergantung pada uraian theologis yang berdasarkan prinsip hermeneutika yang benar. Walaupun diakui bahwa berbagai penafsiran teologis terus mewarnai pembicaraan Soteriologi Kristen, hal tersebut bukan berarti akan menghentikan pembahasan doktrin yang penting ini. Para teolog telah berhasil memberikan kajian teologis dari berbagai sudut pandang. Itulah sebabnya berbagai pendangan Soteriologi dalam teologi Kristen mewarnai banyak diskusi teologi yang ada.

Chris Marantika mengatakan bahwa: Doktrin keselamatan adalah suatu doktrin yang sederhana tetapi juga konpleks. Namun inilah suatu doktrin yang perlu dimengerti secara tepat..${ }^{23}$ Adalah baik mempelajari Soteriologi Kristen dari berbagai sudut pandang karena hal tersebut akan memperkaya khasanah pemikiran orang percaya. Tentunya hal ini harus didukung dengan sikap dewasa tanpa memandang ajaran Soteriologi kelompok lain dalam Kristen secara subjektif. Ingatlah bahwa walaupun cukup beragam warna teologi yang ada saat ini namun hal tersebut tidak boleh menjadi alasan untuk tidak mempelajarinya, karena dengan mempelajari hal yang dimaksud maka akan diperoleh informasi

\footnotetext{
${ }^{21}$ Richard E. Palmer, Interpratation Theory in Schleirmacher, Dilthey, Heidegger, and Gadamer, terj. Mansur Hery dan Damanhuri M, (Yogyakarta: Pustaka Pelajar, 2005), 14.

${ }^{22}$ Ibid, 15.

${ }^{23}$ Chris Marantika, 17.
} 
yang mungkin saja belum pernah didengar selama ini.

Anthony A. Hoekema, dalam buku Diselamatkan oleh Anugerah, menyatakan bahwa: Keselamatan yang sering didiskusikan oleh orang-orang percaya yaitu di dalam Tuhan Yesus Kristus menjadi pergumulan teologis setiap orang yang mengenal jalan keselamatan di dalam Yesus. Studi mengenai penerapan karya penebusan dalam diri umat Allah ini di sebut soteriologi, yang berasal dari dua kata Yunani, soteria dan logos, yang berarti "doktrin keselamatan". ${ }^{24}$ Sebagaimana yang dikatakan Hoekema bahwa diskusi yang terus terjadi berkaitan dengan doktrin Soteriologi Kristen terus berlangsung. Pergumulan mengenai doktrin ini tak pernah sepi sepanjang masa. Pernyataan Hoekema tersebut diatas tidak bisa dianggap sepi karena memang demikian adanya.

Soteriologi Kristen penuh dengan warna karena dampak hermeneutika yang dikaji sedemikian rupa. Haruslah diakui bahwa setiap kajian hermeneutika akan melahirkan suatu konsep yang sesuai dengan kajian hermeneutika yang dilakukan. Pendekatan yang dilakukan merupakan hasil kajian hermeneutika yang memang penuh dengan prinsip-prinsip yang sudah baku, namun penafsiran yang dilakukan masingmasing orang seringkali berbeda satu dengan lainnya. Itulah sebabnya sebagaimana yang sudah disebutkan pada bagian sebelumnya, yaitu bahwa kajian Soteriologi Kristen pada akhirnya menghasilkan banyak warna teologi.

Doktrin teologi Kristen tidak pernah dibangun dengan dasar asumsi dan spekulasi semata. Walaupun hal itu membicarakan aspek masa lalu, kini dan depan, namun karena berdiri atas keyakinan pewahyuan ilahi, maka Soteriologi Kristen memberikan kepastian yang terjamin. Tentunya tanpa mengurangi rasa hormat kepada kepercayaan yang lain, namun dengan tegas dikatakan bahwa Soteriologi Kristen dapat diterima dalam berbagai aspek; sebagai suatu jalan

\footnotetext{
${ }^{24}$ Anthony A. Hoekema, Diselamatkan oleh Anugerah, (Surabaya: Momentum 2006), 1.
}

keluar atas pergumulan hidup yang dihadapi oleh manusia. Semua uraian Soteriologi Kristen disusun berdasarkan Alkitab yang dipandang sebagai Firman Allah. Itulah sebabnya setiap ketidaksesuaian ataupun pertentangan diantaranya dapat dipertemukan dengan menjadikan Alkitab sebagai tolok ukurnya. Orang Kristen harus percaya dan menaruh kepercayaannya terhadap apa yang disampaikan dalam Alkitab. Itulah sebabnya orang Kristen pada umumnya akan sulit menolak fakta biblikal yang disampaikan kepadanya, namun hal itu tidak berlaku dengan para teolog yang memang bergumul dengan hal-hal tersebut.

Diskusi yang berkepanjangan mengenai keyakinan Soteriologi dalam kekristenan telah terjadi sejak awal gereja berdiri. Kajian Soteriologi itu sendiri telah berlangsung sedemikian lama dan melibatnya sangat banyak ahli dalam studi teologi tersebut. Banyaknya orang yang menyatakan sikap setuju dengan suatu ajaran telah menimbulkan hal yang berbeda dengan mereka yang tidak setuju. Pada pihak yang setuju tentu memberikan rasa sukacita, namun bagi mereka yang kurang sependapat akan masuk dalam dunia tanda tanya yang besar, dengan pergumulan yang panjang untuk mencari jawaban atas apa yang dikaji tersebut.

Tidak bisa dipaksakan untuk menerima konsep yang sulit diterima; kesemuanya itu terjadi karena perbedaan pandangan dan juga penafsiran. Namun demikian ada kesamaan dari keyakinan masing-masing pihak berbeda tersebut, yaitu bahwa Yesus adalah Tuhan, dan Dia adalah satu-satunya Juruselamat umat manusia; hanya melalui Dia ada kasih dan pengampunan serta keselamatan kekal. Millard J. Erikcson, dalam buku: Christian Theology, menyatakan: Karena kematian Kristus memiliki nilai yang tak terhingga maka kematian tersebut cukup untuk semua orang pilihan tanpa memandang jumlahnya. Yang dipersoalkan sebenarnya ialah apakah Allah mengutus Kristus untuk menyediakan keselamatan bagi semua orang, atau hanya bagi semua orang yang telah dipilihNya. Jawaban kita tergantung pada pengertian kita 
mengenai urutan logis dari ketetapanketetapan Tuhan. ${ }^{25}$ Erikcson memberikan penjelasan yang baik untuk dipahami berkaitan dengan karya Kristus. Bagi Erikcson, pengorbanan Kristus bagi manusia merupakan sesuatu yang luar biasa dan harusnya dipahami dengan baik oleh setiap orang percaya. Dalam penjelasan tersebut nyata bahwa doktrin Soteriologi Kristen masih menarik perhatian banyak pihak untuk diperbincangkan karena tidak pernah dibangun berdasarkan pengalaman hidup semata. Ada pewahyuan yang memang nyata dalam hal keselamatan umat manusia yang percaya kepada Kristus.

\section{Keberdosaan Manusia}

Dosa telah menjadi masalah besar dalam kehidupan manusia, dan Alkitab mengajarkan bahwa dosa masuk ke dunia karena pelanggaran Adam dan Hawa yang tidak mampu melawan godaan Iblis (Kej. 3). Manusia jatuh ke dalam dosa karena dipengaruhi oleh Iblis (Yoh. 8:44; Rom. 16:20). Akibat dari perbuatannya itulah maka manusia mendapat hukuman dari Tuhan Allah dan hilang akan kemuliaan Allah dalam dirinya serta mengalami kematian (Kej. 3:19; Rom. 3:23; 5:12; 6:23). Dalam pengertian yang sederhana, dosa digambarkan Alkitab sebagai pelanggaran hukum Allah (1 Yoh. 3:4) dan pemberontakan melawan Allah (Ul. 9:7; Yos. 1:18). Dalam arti umumnya, dosa berarti Perbuatan yang melanggar hukum Tuhan atau agama, atau perbuatan salah.

Alkitab Perjanjian Lama memberikan pengertian yang sedemikian lengkap tentang dosa dan dijelaskaan dalam beberapa istilah berikut ini, yaitu: Kata Ibrani Hātạa yang berarti berdosa, bersalah, berbuat jahat, tidak mengenai sasaran (Im. 4:2,3,2535; Maz. 1:5; 51:2-5; Yes. 53:10,12; Hak. 20:16; Ams. 8:6;19:2). Kata $R \bar{a}^{\prime} a^{\prime}$ (רָע), yang memiliki pengertian jahat, merugikan

\footnotetext{
${ }^{25}$ Millard J. Erickson, Christian Theology Jilid 3, (Malang: Penerbit Gandumas, 2003), 509-510.
}

dan menghancurkan, menjadi jahat. Kata ini juga menunjuk kepada aktivitas apapun yang menolak kehendak Tuhan dan menunjukkan sikap yang menolak otoritas Tuhan. (1 Raj. 14:9; Ams. 4:16; Yes. 1:16; 11:9). Mereka ditandai dengan kurangnya pemahaman sikap (Yer. 4:22) dan sengaja merencanakan untuk menyakiti orang lain (Ams. 24:8), bahkan terbiasa dan kompulsif (Yer. 13:23; Kej. 19:9; Ams. 4:16; 17:4). Kata Ibrani Pāša

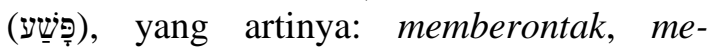
langgar, dan pemberontakan. Kata Pāša (עשָׁ) pada dasarnya menunjukkan suatu pelanggaran yang agresif terhadap perjanjian sipil atau keagamaan di antara kedua pihak. Dalam arti agama, hal itu menandakan dosa memberontak seperti ketika bangsa Israel yang menjalani kehidupan yang tidak sesuai komitmen; dengan cara melanggar perjanjian Allah (Yes. 1:28; 48:8; Yeh. 2:3; Hos. 8:1). Kata Ibrani ' '̄wōn yang berasal dari kata 'Āwāh (עָוָָ), berarti: untuk berbuat salah, dosa, kebusukan; rasa bersalah; kriminalitas, kejahatan, kesalahan; hukuman. Kata ini menunjukkan adanya kelakuan buruk dan konsekuensinya, lebih fokus pada kesalahannya. Hal tersebut membuktikan banyak jumlah atau seringnya pelanggaran di masa lalu terhadap Allah maupun sesama manusia (Bil. 14:34; 1 Sam. 25:24; 2 Sam. 22:24; 1 Raj. 17:18; Ez. 9:6; Yes. 1:4; Yer. 11:10). Kata Šāgag (ָㅜ) yang dapat dijumpai dalam kitab Mazmur 119:67 dengan artinya tersesat dalam perjalanan, dan Imamat 5:18 serta Bilangan 15:28, yang memiliki pengertian berbuat dosa dengan

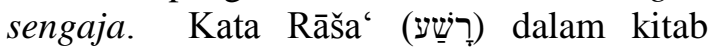
Keluaran 22:9; Ulangan 25:1; Yesaya 50:9, memiliki pengertian menjadi kafir atau tidak bertuhan, menjadi jahat, menjadi najis, untuk menghukum, menyatakan bersalah, dan mengutuk. Kata Āšām (wָָָָ) yang artinya adalah: menjadi bersalah, dosa, kesalahan, pelanggaran, korban penebus salah. (Im. 6:17; Yeh. 40:39). Kata Tā'āh (הָָּ ) yang artinya: mengembara hingga tersesat secara 
mental, moral, spiritual. (Kej. 21:14; Maz. $58: 3 ; 95: 10){ }^{26}$

Alkitab Perjanjian Baru memberikan informasi tentang pengertian dosa yang dalam bahasa Yunani adalah sebagai berikut:

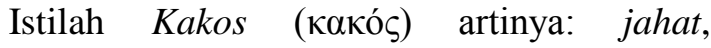
kejahatan (Mat. 21:41; 24:48; Mark. 7:21),

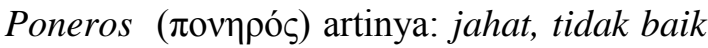
(Mat. 6:23; 7:17,18), jahat (Ef. 5:16; 6:13; Wah. 16:2), jahat, malas (Mat. 25:26; Luk.

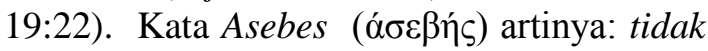
hormat kepada Allah, durhaka, penuh dosa

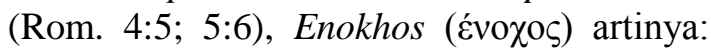
dalam perhambaan (Ibr. 2:15), jijik, harus dihukum (Mat. 5:21,22; 26:66; Mark. 3:29; 14:64), berdosa terhadap (1 Kor. 11:27; Yak.

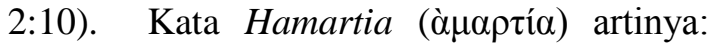
kesalahan, dosa (Mat. 1:21), hukum atau penyebab dosa (Rom. 7:17,20), kesalahan karena dosa diperhitungkan (Yoh. 9:41; Ibr. 9:26), mempersembahkan korban karena dosa, korban penebusan dosa (2 Kor. 5:21).

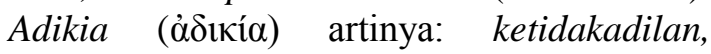
kefasikan, kejahatan, penipuan, keliru (1 Pet.

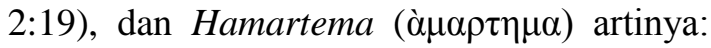
tidak kena sasaran, berdosa (1 Kor. 15:34; Tit. 3:11), berbuat dosa (Yoh. 5:14), bersalah melakukan kesalahan (Mat. 18:15), dosa (Mar. 3:28; 4:12; Rom. 3:25; 1 Kor. 6:18).

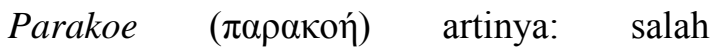
mendengar, ketidaktaatan, kedurhakaan (2

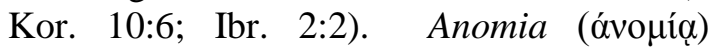
artinya: prilaku tanpa hukum (1 Yoh. 3:4), kejahatan, dosa (Mat. 7:23). Paranomia $(\pi \alpha \rho \alpha v o \mu i ́ \alpha)$ artinya: pelanggaran hukum, kejahatan (2 Petr. 2:16). Parabasis ( $\pi \alpha \rho \alpha ́ \beta \alpha \sigma \iota \varsigma)$ artinya: berlangkah di pinggir, penyimpangan, pelanggaran, dosa (Rom. $2: 23 ; 4: 15)$. Paraptoma ( $\pi \alpha \rho \alpha ́ \pi \tau \omega \mu \alpha)$ artinya: tersandung; kesalahan, pelanggaran (Mat. 6:14,15; Mark. 11:25,26; Rom. 4:25), kejatuhan, salah gunakan iman (Rom.

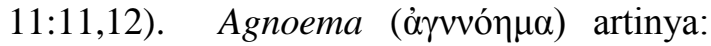
kesalehan, pelanggaran yang diperbuat dengan tidak sadar, dan Hettema ( yang berarti kekurangan (karena tidak sesuai

\footnotetext{
${ }^{26}$ Charles C. Ryrie, Basic Theology: A Popular Systematic Guide to Understanding Biblical Truth, (Chicago: Moody Publishers, 1999), 213 214.
}

dengan pola yang ada), dan kegagalan (Rom. 11:12; 1 Kor. 6:7). ${ }^{27}$

Dari sejumlah pengertian tersebut diatas, maka Alkitab memberikan pengertian mengenai dosa, dimana dosa dianggap sebagai pelanggaran hukum, Dosa ialah pelanggaran hukum Allah. (1 Yoh. 3:4). Semua kejahatan adalah dosa (1 Yoh. 5:17). Tidak melakukan yang baik, Jika seorang tahu bagaimana ia harus berbuat baik, tetapi ia tidak melakukannya, ia berbuat dosa. (Yakobus 4:17). Ketidakpercayaan adalah dosa. Dan segala sesuatu yang tidak berdasarkan iman, adalah dosa. (Rom. 14:23), dan bahkan memikirkan kebodohan adalah dosa (Ams. 24:10).

Alkitab menyatakan bahwa semua orang telah berbuat dosa (Rom. 3:23), namun dalam sejarah gereja, khususnya Gereja Katolik, doktrin Maria Immaculata dianggap pengecualian. Gereja Katolik percaya bahwa bunda Maria tidak sama dengan manusia biasa lainnya, yang lahir dan bergumul dengan dosa; baik dosa asal, maupun dosa perbuatannya. Groenen C., dalam buku Mariologi, Teologi dan Devosi, menyatakan: Dogma umat Katolik menyatakan bahwa Maria tidak terkena dosa asal, karena kasih karunia Allah, pilihan Allah berdasarkan karya penebusan Yesus Kristus, anaknya sendiri. Karya penebusan itu sudah efektif terjadi jauh sebelum Yesus Kristus itu ada. Dogma itu tidak mengatakan bahwa Maria ditebus tetapi Maria 'sebelumnya' terlindung atau terpelihara (praeservata). ${ }^{28}$ Bagi Groenen, umat Katolik sangat meyakini akan ketidakberdosaan Maria sebagai bunda Yesus, dan hal itu berlaku hingga kini. Maria dianggap suci karena melahirkan Yesus dan juga karena sifat kesucian yang diberikan Tuhan Allah atas dirinya. Hugo Rahner, dalam buku Our Lady and the Church, berkata: But this mystery of the Immaculate Conception of Mary is not only a personal priviledge granted to her who was to become the Mother of God. Mary thereby become the figure of the Church......The word

\footnotetext{
${ }^{27}$ Ibid.

${ }^{28}$ Groenen C., Mariologi, Teologi dan Devosi, (Yogyakarta: Penerbit Kanisius, 1994), 9.
} 
'immaculate' indeed sums up the mystery of our own spiritual life. We are members of the Church, and in us the Church's mystery must be accomplished; it begins with Mary Immaculate, and we in turn, by the power of the Holy Spirit, must once more become immaculate. In each of us the victory over the serpent must be achieved.... ${ }^{29}$ Bagi Rahner, misteri Immaculate Conception yang ada pada Maria bukan hanya hal istimewa yang diberikan kepadanya sebagai Bunda Allah. Umat Katolik sangat percaya dengan konsep tersebut.

Menurut teolog Katolik, Nico Syukur, Maria tidak punya tugas pewartaan. Tugas itu bukan hanya keterikatan kekeluargaan (Lukas 8:19-21). Maria terlibat dengan seluruh pribadinya dalam peristiwa yang berlangsung. Fakta keselamatan disimpan Maria dalam hatinya dan direnungkannya (Lukas2:19). Tugas Maria yaitu tugas Israel dan tugas gereja serentak. Di satu pihak Maria telah menjadi gambar termurni dari Israel yang menanti-nanti, dan di lain pihak Maria menjadi contoh Gereja yang menyambut Yesus sang Kristus. Zaman lama diaplus dengan zaman baru. Maria menerima Yesus pertama-tama dalam hati dan budinya baru kemudian dalam kandungannya atau prius mente concepitquam ventre. ${ }^{30}$

Membicarakan hal Soteriologi Kristen, tentunya tidak dapat mengabaikan hal dosa didalamnya. Chris Marantika berkata: Doktrin keselamatan atau Soteriologi tak berarti tanpa dosoroti dari sudut kekejaman dosa. ${ }^{31}$ Walaupun pembuktian berdasarkan sejumlah data dan bukti lainnya; yang seolaholah menyatakan bahwa ada manusia lain yang tidak berdosa, maka hal tersebut akan membawa kepada suatu diskusi yang panjang. Jika memahami Alkitab dengan baik, maka kenyataan bahwa semua orang telah berbuat dosa dan telah kehilangan kemuliaan Allah; merupakan fakta yang tak terbantahkan.

\footnotetext{
${ }^{29}$ Hugo Rahner, Our Lady and the Church, (Bethesda: Zaccheus Press, 1990). 17, 20.

${ }^{30}$ Nico Syukur Dister, Kristologi sebuah Sketsa, (Yogyakarta: Penerbit Kanisius, 1994), 248.

${ }^{31}$ Chris Marantika, 38.
}

Tokoh gereja, Augustinus (354-430) tidak memandang dosa sebagai sesuatu yang positif, tetapi merupakansesuatu penyangkalan atau keadaan yang serba kurang. Manusia diciptakan untuk kekal, bukan berarti dia tidak dapat mati tetapi dia memiliki kesanggupan untuk hidup yang kekal. Menurutnya, keadaan manusia dari posse non peccare et mori, yaitu mampu untuk tidak berdosa dan mati; dia akan melewati keadaan non posse peccare et mori yaitu tidak mampu untuk berdosa dan mati. Tetapi dia berdosa dan konsekuensinya memasuki keadaan non posse non peccare et mori (tidak mampu untuk tidak berdosa dan mati). ${ }^{32} \quad$ Lebih lanjut Augustinus mencoba untuk menggambarkan dosa sebagai hal yang hakiki melekat pada hakekat manusia. Dosa merupakan suatu aspek yang integral, bukan opsional, dari keberadaan kita. Manusia dengan cara dan kemampuannya sendiri tidak pernah dapat masuk ke dalam suatu hubungan dengan Allah. Tak satu pun perbuatan manusia yang dapat mematahkan belenggu dosa. Karenanya Allah turut campur dalam dilema manusia. ${ }^{33}$

\section{Doktrin Keselamatan Dalam Kristus}

Penggunaan istilah Soteriologi dalam teologi Kristen yang berarti doktrin tentang keselamatan, pada dasarnya memberi ruang yang luas kepada pemahaman yang inklusif. Tentunya hal ini tidak terlalu disukai oleh mereka yang mendalami pola kehidupan yang bersandar pada pemahaman theologi religionum. Namun demikian kenyataan bahwa keselamatan hanya ada dalam Yesus Kristus, merupakan keputusan yang sudah final berdasarkan wahyu Tuhan. Dieter Becker dalam buku Pedoman Dogmatika mengatakan: Dalam Perjanjian Baru dapat

\footnotetext{
${ }^{32}$ Louis Berkhof, The History of Christian

Doctrines, (Grand Rapids, Michigan:

Wm.B.Eerdmans Publishing Company, 1953), 138

${ }^{33}$ Alister E.McGrath, Sejarah Pemikiran

Reformasi, (Jakarta: BPK. Gunung Mulia, 2002), 93.
} 
disimpulkan dengan pernyataan bahwa Allah melalui Yesus Kristus telah mengerjakan keselamatan bagi umat manusia. Dalam hal ini Perjanjian Baru lebih menekankan peran Kristus dari pada hakikat-Nya, lebih menonjolkan perbuatan-Nya dari pada keberadaanNya; atau dengan kata lain, kesiapan Yesus itu tampak melalui apa yang Ia perbuat dan hakikat-Nya diketahui hanya melalui karya keselamatan-Nya. ${ }^{34}$

Dalam upaya untuk menjelaskan konsep Soteriologi Kristen, maka diperlukan usaha untuk memahaminya karena nyata sekali adanya beberapa kelompok yang memberikan argumentasinya berkaitan dengan Soteriologi itu sendiri.

Alkitab memberikan banyak bukti bahwa Yesus Kristus adalah satu-satunya jalan keselamatan. Yesus Kristus akan datang untuk menghakimi dunia (Mat. 25:3146), Dia menyatakan diriNya sebagai Tuhan (Mark. 2:27-28 dan Kel. 20:8-11). Yesus sendiri menyatakan diri bahwa Ia satu dengan Allah (Yoh. 10:30), bahkan dikatakan bahwa orang yang sudah melihat dan mengenal Yesus berarti ia juga telah melihat dan mengenal Allah (Yoh. 14:7-9). Yesus kristus dama sama seperti Allah kekal adanya (Yoh. 8:58). Perkataan yang diucapkanNya memiliki otoritas yang sama dengan firman yang tertulis dalam Perjanjian Lama (Mat. 5:21-22), dan mujizat yang dilakukan Yesus, yaitu membangkitkan orang mati merupakan salah satu dasar untuk menyatakan bahwa Dia adalah Allah (Yoh. 5:21).

Keselamatan hanya ada dalam Yesus Kristis, karena para rasul melihatNya sebagai pribadi ilahi. Mereka memanggilNya Mesias, dengan mengatakan: "Engkau adalah Mesias, Anak Allah yang hidup" (Mat. 16:13-16). Juga seorang murid Yesus menyebutNya sebagai Tuhan, dengan berkata: "Ya Tuhanku dan Allahku" (Yoh. 20-28). Rasul Yohanes memberikan kesaksian tentang Yesus sebagai Allah (Yoh. 1:1 band. Yoh. 1:8). Rasul Paulus menyebut Yesus Kristus sebagai: "gambar Allah yang

\footnotetext{
${ }^{34}$ Dieter Becker, Pedoman Dogmatika, (Jakarta: Gunung Mulia, 1991), 112-114.
}

tidak kelihatan, ... tidak ada satu yang tidak diciptakan olehNya". (Kol. 15:20), dan terakhir penulis kitab Ibrani menyatakan bahwa Yesus Kristus adalah cahaya kemuliaan Allah dan gambar wujud Allah, dan hal ini pun merupakan salah satu dasar untuk menyatakan bahwa Yesus Kristus adalah Tuhan dan Juruselamat bagi umat manusia (Ibr. 1:3).

\section{Doktrin Soteriologi Gereja Katolik}

Dalam perjalanaan sejarah gereja, sikap tegas yang diambil untuk menyatakan eksistensi kegerejaannya adalah dengan menyatakan bahwa keyakinan gereja sudah final, yaitu Yesus Kristus adalah Tuhan dan juruselamat umat manusia. Itulah sebabnya semboyan Extra Ecclesiam Nulla Salus, merupakan sebuah ungkapan yang untuk pertama kalinya diucapkan Siprianus (200258) atau Cyprianus ${ }^{35}$ dari Karthago pada abad ketiga dan ungkapan tersebut dapat ditemukan di antara surat-suratnya. Semboyan tersebut sesungguhnya hendak menyampaikan sikap tegas gereja yang pada

\footnotetext{
${ }^{35}$ Cyprianus adalah uskup Karthago, Afrika Utara, dalam suatu kesempatan, Cyprianus berselisih dengan Stephanus, uskup Roma, mengenai sah atau tidaknya baptisan kaum bidat. Baginya baptisan tersebut tidak sah, sementara uskup Roma menyatakan sebaliknya. Bagi Cyprianus gereja adalah ibu orang percaya dan bidat bukanlah gereja, mereka bukanlah orang Kristen. Itulah sebabnya ia berkata: "Uskup dalam gereja dan gereja dalam uskup dan jika ia tidak bersama uskup maka ia tidak berada dalam gereja." Tidak ada keselamatan di luar gereja (Extra ecclesiam nulla sallus). Ketika diadili Paternus, Gubernur Afrika, Paternus, dengan berani, Cyprianus mengakui dirinya sebagai seorang Kristen dan uskup. Cyprianus berkata: "Saya seorang Kristen dan uskup. Saya tidak mengakui dewa-dewa lain di samping Allah yang satu dan benar itu, yang menjadikan langit dan bumi, laut dan segala isinya. Kami orang Kristen mengabdi kepada Allah; kepada Dia kami berdoa siang dan malam untuk kami dan untuk semua orang dan untuk keselamatan kaisar-kaisar sendiri." Setelah sempat dibuang ke kota Curubis, Cyprianus menjadi martir pada tanggal 14 September 258.
} 
waktu itu berhadapan dengan berbagai aliran filsafat dan juga isme-isme baru yang muncul pada masa tersebut.

Gereja dengan doktrin Soteriologi-nya hendak menyatakan eksistensi dirinya sebagai lembaga yang memiliki otoritas untuk menentukan hal Soteriologi umatnya. Itulah sebabnya adigium tersebut disampaikan secara terbuka dengan maksud mempertegas posisi dan sikap gereja mengenai keselamatan umat manusia.

Ungkapan Extra Ecclesiam Nulla Salus kemudian muncul dalam dokumen resmi dari Konsili Lateran $\mathrm{IV}^{36}$ yang mengatakan bahwa: Hanya ada satu gereja umat yang universal, dan di luar gereja itu tidak ada yang diselamatkan. Kemudian dalam perkembangan sejarah, banyak bapak gereja memberikan komentar dan penafsiran atas ungkapan tersebut.

Pada dasarnya ajaran Gereja Katolik mengakui Yesus sebagai Tuhan dan Juruselamat serta keselamatan adalah anugerah dari Allah. Namun Gereja Katolik punya konsep keselamatan tersendiri. Dalam ajaran Katolik, orang yang diselamatkan adalah orang yang mengimani Yesus Kristus sebagai Tuhan dan Juruselamat serta mengimani bahwa Gereja Katolik adalah satu-satunya agen keselamatan. Jadi ada persyaratan tambahan didalamnya, sehingga dapatlah dikatakan bahwa keselamatan dalam Gereja Katolik tidak ada agen lain yang dapat membawa keselamatan selain Gereja Katolik itu sendiri. Keyakinan akan Yesus sebagai Tuhan dan Juruselamat dalam keyakinan

\footnotetext{
${ }^{36}$ Konsili Lateran IV yang dilaksanakan pada tahun 1215 merupakan konsili terpenting dari semua Konsili Lateran karena dalam konsili yang berlangsung hanya dalam waktu tiga hari mampu menghasilkan sejumlah dekrit penting bagi gereja. Konsili ini merupakan yang paling penting pada abad pertengahan karena puncak dari kuasa Paus Innocentius yang menginginkan kepausan mengontrol berbagai urusan gerejawi dan negara. Apabila para paus yang terdahulu menjuluki dirinya sebagai wakil Petrus, maka Paus Innocentius menuntut hak sebagai wakil Kristus. Melalui Konsili ini juga doktrin Transubstansiasi yaitu bahwa roti dan anggur berubah menjadi substansi tubuh dan darah Kristus, resmi diterima.
}

Gereja Katolik nyata, namun sesuai dengan doktrin Gereja Katolik, ada penambahan unsur lain didalam keyakinan iman tersebut, diantaranya adalah percaya akan tradisi gereja yang berkembang turun-temurun.

Gereja Katolik mendominasi sejarah gereja sebelum masa reformasi. Mereka sangat berpengaruh dalam kehidupan masyarakat Eropa kala itu, dan bahkan mereka mampu menentukan arah kehidupan suatu bangsa di Eropa. Gereja Katolik sangat kuat pengaruhnya sebelum Martin Luther (1483-1546), ${ }^{37}$ dan konsentrasi pemikiran filosofis juga terarah ke sana. Ajaran Katolik juga meyakini bahwa masih ada terbuka peluang keselamatan bagi mereka yang tidak masuk dalam anggota Gereja Katolik. Dengan catatan, orang ini sama sekali tidak bisa atau tidak pernah mendengar ajaran Gereja Katolik, tapi selalu mencari akan kebenaran yang sejati dan tidak banyak berbuat dosa. Ini yang dinamakan dengan invisible ignorant, dalam ajaran Katolik. R. C. Sproul, dalam buku Kebenaran-kebenaran Dasa Iman Kristen, mengatakan: Teologi Roma Katolik berbicara tentang amal-baik dengan tiga cara yang berbeda. Pertama, amal-baik yang terhormat, amal itu begitu terhormat sehingga harus diberi upah. Kedua, amal-baik yang serasi atau pantas, meskipun ini bukan amalbaik yang terhormat, amal-baik ini serasi dan pantas mendapatkan penghargaan dari Allah. Amal-baik yang serasi ini dicapai dengan melakukan perbuatan baik seturut dengan sakramen pertobatan. Tipe ketiga dari amal-

\footnotetext{
${ }^{37}$ Martin Luther (1483-1546) tadinya seorang rahib Katolik yang kemudian menjadi pelopor bagi Reformasi gereja. Pada tanggal 31 Oktober 1517, Luther menempelkan 95 dalil di pintu gerbang gereja di Wittenberg. Ada banyak hal yang hendak dikoreksinya, namun ada satu hal yang paling menonjol dan tercatat dalam peristiwa tersebut, yaitu ketika Johann Tetzel, seorang imam Dominikan, melakukan penjualan Indulgensi. Atas tindakannya itu maka Luther dianggap sesat oleh Paus Leo X, namun gerakan Luther untuk mereformasi gereja terus berlanjut. Gerakan dipelopori Luther terus tersebar ke berbagai tempat dan berkembang menjadi gereja baru.
} 
baik ini adalah amal-baik yang luar biasa, yaitu amal-baik yang melampaui apa yang dituntut. Amal-baik ini merupakan hal yang dicapai oleh orang-orang kudus. Amal-baik ini ditabung ke dalam tabungan amal-baik di mana gereja dapat mengambilnya bagi orangorang kekurangan amal-baik untuk dapat melewati api penyucian (purgatori) menuju surga. ${ }^{38}$

Perlu diketahui bahwa keyakinan teologi Kristen menyangkal dan bahkan memprotes ketiga pengertian amal-baik tersebut diatas, dan menyatakan bahwa amalbaik yang orang percaya adalah amal-baik dari Kristus.

Karya Kristus datang pada diri setiap orang melalui kasih karunia berdasarkan iman kepadaNya semata. Kasih karunia merupakan belas kasihan Allah yang diberikan bukan berdasarkan amal-baik dari seseorang (Ef. 2:8-9). Keselamatan merupakan tindakan atau inisiatif Allah terhadap manusia. Kasih karunia bukan merupakan substansi yang dapat mendiami jiwajiwa. Seseorang bertumbuh di dalam anugerah, bukan berdasarkan ukuran secara kuantitas dari substansi di dalam diri seseorang. ${ }^{39}$

Keselamatan yang diperoleh manusia bukanlah suatu usaha dan hasil dari kerja kerasnya (Ef. 2:8-9); melainkan sebuah kasih karunia, yaitu sesuatu yang diberikan Tuhan Allah secara cuma-cuma bagi dirinya. Pengajaran bahwa keselamatan sebagai pemberian dan anugerah dari Tuhan Allah seringkali tidak dipahami dengan utuh. Konsep inilah yang seringkali diabaikan manusia karena banyak orang berpikir secara keliru mengenai Soteriologi. Perkiraan bahwa setiap usaha mendatangkan keselamatan bagi dirinya adalah hal yang keliru.

H. Wayne House dalam buku Charts of Christian Theology \& Doctrine, memberi arti keselamatan sebagai penerimaan anugerah dari Allah melalui gereja yang

\footnotetext{
${ }^{38}$ R. C. Sproul, Kebenaran-kebenaran Dasar Iman Kristen, (Malang: Seminari Alkitab Asia Tenggara, 1997), 263.

${ }^{39}$ Ibid, 263-264.
}

kemudian berkembang menjadi: Receiving grace either through nature or the church. ${ }^{40}$ Lebih lanjut House menambahkan: Catholics are incorporated into the church; nonChatolic Christians are linked to the church; non-Christians are related the church. ${ }^{41}$ House melihat bahwa yang menjadi rintangan atau halangan dari pendapat yang lama adalah: Unconfessed mortal sins. Sedangkan Means of Salvation oleh Katolik Roma dianggap sebagai pendapat baru: Penerimaan anugerah melalui partisipasi di dalam sakramen-sakramen gereja; pendapat kemudian: Receiving grace through either or the sacraments of the church. ${ }^{42}$

George Barker Stevens dalam buku yang berjudul The Christian Doctrine of Salvation, menyampaikan adanya pertentangan antara Protestan dan Roma Katolik, berkaitan dengan doktrin soteriologi sebagai berikut: Now our Protestant theology has shown a strong preference for this Pauline maxim of justification by faith as against the Roman Catholic emphasis upon participation in rites and ceremonies considered as conditions of salvation. To the Catholic mind the protestant view has seemed one-sided because, it is said, it eventuates in the error codemned by James, a faith without works, which dead. To the protestant on the other hand, the Catholic theory of salvation has seemed to be only $\mathrm{s}$ Christianized Pharisaism a doctrine of salvation by ceremonial acts which is in principle the very error agaist which Paul so energetically contended. ${ }^{43}$

Ajaran umum dari gereja Katolik bagi umatnya meliputi beberapa aspek, yaitu: Mengikuti Kristus, karena Dia adalah Jalan, Kebenaran dan Hidup (Yoh. 14:6); Jalan, karena Dia yang membuka jalan, sehingga surga terbuka kembali dengan sengsara,

\footnotetext{
${ }^{40}$ H. Wayne House, Charts of Christian Theology and Doctrine, (Michigan: Zondervan, 1992), 92. of Salvation, (New York: Charles Scribner's Sons, 1911), 452-453.
} 
wafat, dan kebangkitan-Nya. Kebenaran, karena Dia adalah Tuhan, yang menjadi kebenaran mutlak, dan Hidup, sebab Dia yang Tuhan yang memberikan kehidupan, dan yang mengikuti-Nya akan memperoleh hidup kekal. Selain itu, umat Katolik juga harus menerima tujuh sakramen, diantaranya: Sakramen Inisiasi, yaitu: Pembaptisan, Penguatan atau Krisma dan Ekaristi; Sakramen Penyembuhan, yaitu: Rekonsiliasi dan Pengurapan Orang Sakit; Sakramen Panggilan, yaitu: Imamat dan Pernikahan. Selain sakramen tersebut, umat wajib menjadi anggota Gereja Katolik.

\section{Doktrin Soteriologi Kristen}

Salah satu praktek gereja yang dianggap menyimpang pada masa Martin Luther adalah Indulgensia. $^{44}$ Gereja Katolik pada waktu itu menyampaikan doktrin tersebut bukan karena dasar biblika, melainkan karena suatu kebutuhan yang mendesak sehingga dengan terpaksa doktrin Indulgensia digulirkan kepada warga gereja. Apa yang dilakukan Gereja Katolik tersebut menuai masalah, dan masalah ini dianggap sebagai salah satu pemicu terjadinya gerakan Reformasi Gereja oleh Martin Luther, karena tidak dapat tidak dapat menerima praktek yang dianggap bertentangan dengan prinsip Alkitab tersebut. Puncaknya adalah dengan merumuskan 95 dalil dan ditempelkannya di

\footnotetext{
${ }^{44}$ Indulgensia adalah surat pengampunan dosa, dimana pada masa Pemerintahan Paus Leo X kegiatan tersebut bertujuan untuk pembangunan Gereja Rasul Petrus di Roma, dan pelunasan hutang Uskup Agung Albrecht dari Mainz. Dalam doktrin yang disusun mengenai Indulgensia, seseorang dapat memiliki surat pengampunan dosa tersebut dengan cara membelinya. Penjualan surat pengampunan dosa dianggap telah melampaui batas-batas pemahaman teologis yang benar karena mereka mengatakan bahwa bahwa pada saat mata uang berdering di peti, maka jiwa akan melompat dari Api Penyucian ke Surga, bahkan dikatakan juga bahwa surat Indulgensia itu dapat menghapuskan dosa.
}

pintu gerbang gereja Wittenberg pada tanggal 31 Oktober 1517.

Setelah peristiwa penempelan 95 dalil, sebagai sebuah koreksi Luther atas gereja pada waktu itu, maka reaksi keras dari pemimpin gereja pada waktu itu juga nyata dan hal itu terlihat dengan jelas dari suatu sikap yang dikeluarkan gereja Katholik terhadap Luther. Reaksi keras itu nyata dari bulla yang dikeluarkan pemimpin gereja pada waktu itu, yaitu bulla exurge Domine ${ }^{45}$ yang dikeluarkan pada tanggal 15 Juni 1520. Dalam bulla tersebut, Paus menyatakan bahwa pandangan Luther itu menyesatkan dan harus ditarik kembali. Jika tidak maka ia dianggap melawan gereja dan pada masa itu hukumannya adalah mati. Namun demikian Luther membalas bulla itu dengan suatu karangan yang berjudul Widder die Bullen des Endchrists ${ }^{46}$, dan pada tanggal 10 Desember 1520, Martin Luther membakar bulla Paus tersebut bersama-sama dengan Kitab Hukum Kanonik Gereja Katolik Roma di depan gerbang kota Wittenberg dengan disaksikan oleh sejumlah besar mahasiswa dan profesor Universitas Wittenberg.

Oleh banyak kalangan menilai bahwa tindakan Luther tersebut merupakan tanda pemutusan hubungannya dengan Gereja Katolik Roma. Setelah tindakan Luther tersebut, lalu keluarlah bulla kutuk Paus pada

\footnotetext{
${ }^{45}$ Bulla Exurge Domine merupakan sebuah bulla kepausan yang dikeluarkan oleh Paus Leo X pada tanggal 15 Juni 1520; sebagai tanggapan atas ajaran-ajaran Martin Luther yang terdapat dalam 95 dalil, yang isinya adalah menentang wibawa gereja pada waktu itu. Kalimat Exsurge Domine berarti Bangkitlah, O Tuhan. Walau bulla ini tidak secara langsung mengutuk semua hal dari doktrindoktrin Luther, bulla ini hanya meminta Luther untuk menarik kembali 41 kesalahan dari 95 dalil yang disampaikannya itu. (lih. www. Wikipedia, tentang: Exsurge Domine)

${ }^{46}$ Karangan Martin Luther yang berjudul "Widder die Bullen des Endchrists" atau atau "Melawan bulla yang terkutuk dari si Anti-Kris" merupakan reaksi Luther atas diterimanya Bulla Exurge Domine yang dikeluarkan gereja sebagai reaksi atas tindakan Luther yang menempelkan 95 dalil di pintu gerbang gereja Wittenberg, Jerman pada tanggal 31 Oktober 1517.
} 
tanggal 3 Januari 1521. Inti ajaran Martin Luther berpusat pada tiga semboyan reformasi, yaitu: Sola Gratia atau hanya oleh anugerah, Sola Fide atau hanya oleh iman dan Sola Scriptura atau hanya didalam Alkitab. Ketiga semboyan ini merupakan jawaban dan juga koreksi atas keyakinan gereja yang dianggap luther sudah menyimpang. Ketiga semboyan berbahasa Latin ini menjadi begitu terkenal karena ketiga hal tersebut merupakan intisari dari koreksi Luther bagi gereja yang sudah dianggapnya menyimpang karena mengabaikan apa yang dinyatakan dalam Alkitab. Luther berpendapat bahwa manusia diselematkan bukan karena usaha yang dilakukannya.

Koreksi Luther terhadap Indulgensia sangat jelas kala itu. James Montgomery Boice, dalam buku, Romans, mengatakan: Pembenaran adalah memang jawaban Allah bagi semua pertanyaan manusia yang paling penting: Bagaimana seorang pria atau wanita dibenarkan dengan Tuhan? Kita tidak dibenarkan dengan Tuhan dengan sendirinya. Kita berada di bahwa murka Allah. Pembenaran adalah sangat penting, karena kita harus dibenarkan dengan Allah atau kita binasa selamanya... Kesulitannya adalah mayoritas orang saat ini tidak merasakan kebutuhan di area ini. Martin Luther telah merasakannya; hal itu menghantuinya. Ia tahu bahwa ia tidak benar dengan Allah, dan ia mengantisipasi konfrontasi dengan Allah yang murka di penghakiman terakhir. Allah menunjukkan kepadanya bahwa ia bisa mengalami hubungan yang benar dengan Allah melalui pekerjaan Yesus Kristus. Tetapi di jaman ini siapa yang merasakan intensitas kepedihan Luther? ${ }^{47}$

Martin Luther begumul benar dengan kitab Roma, dan pada suatu hari ia membuka kitab Roma dan membaca tentang injil Kristus yang adalah kekuatan Allah untuk keselamatan (Rom. 1:16). Ini adalah sebuah kabar baik! Namun kalimat Sebab di dalamnya nyata kebenaran Allah, dimana ada

\footnotetext{
${ }^{47}$ James Montgomery Boice, Romans, Vol. I, (Grand Rapids, MI: Baker Book House, 1991), 380, 447.
}

kebenaran, dan hal itu menjadi sebuah tekanan dalam kehidupannya. Luther menjadi depresi karena ia meneruskan membaca tentang murka Allah nyata dari sorga atas segala kefasikan dan kelaliman manusia (Rom. 1:18).

Dalam pergumulannya itu, Luther memperoleh pencerahan tentang hal Kebenaran Tuhan yang Paulus maksud di sini bukanlah keadilan Tuhan yang bersifat menghukum yang membuatNya menghukum orang berdosa, melainkan kebenaran yang Tuhan berikan kepada orang berdosa yang membutuhkan, dan yang orang berdosa itu terima dengan iman. Ini adalah kebenaran yang sempurna dan tidak bercacat, didapatkan oleh Kristus, yang dengan kemurahan Tuhan berikan pada semua yang percaya. Luther tidak perlu lagi mencari dasar untuk kedamaian jiwa di dalam dirinya, di dalam perbuatan baiknya sendiri. Sekarang ia dapat melihat lepas dari dirinya sendiri dan melihat kepada Kristus, hidup dengan iman daripada bersembunyi dalam ketakutan. Pada saat itulah Reformasi Protestan lahir. ${ }^{48}$ Sinclair Ferguson, dalam buku The Christian Life: A Doctrinal Introduction, mengatakan: Renungkan Roma 1:17, Frase kunci apa di ayat ini yang merevolusi pengertian Martin Luther tentang keselamatan? Bagaimana pengaruhnya bagi Anda? Luther melanjutkan dengan berkata bahwa doktrin pembenaran adalah doktrin yang olehnya Gereja berdiri atau jatuh. Doktrin ini merupakan kepala dan batu penjuru Gereja yang melahirkan, memelihara, membangun dan melindungi Gereja. Tanpanya gereja Tuhan tidak dapat bertahan hidup untuk satu jam. ${ }^{49}$

Pada bagian lainnya, Luther ia menambahkan, "Bila doktrin pembenaran ini hilang, maka semua doktrin kekristenan yang benar hilang." ${ }^{50}$ Pembenaran merupakan sebuah istilah untuk mendeklarasikan diri

\footnotetext{
${ }^{48}$ Anthony Hoekema, Saved by Grace, 152.

${ }^{49}$ Sinclair Ferguson, The Christian Life: A Doctrinal Introduction, (Carlisle, PA: The Banner of Truth Trust, 1989), 80.

${ }^{50}$ John R.W. Stott, Only One Way: The Message of Galatians, (Downers Grove, IL: InterVarsity Press, 1968), 60.
} 
benar, dan Anthony Hoekema, dalam buku Saved by Grace, mendefinisikan pembenaran sebagai "Perubahan permanen dalam hubungan yuridis kita dengan Tuhan dimana kita diampuni dari tuduhan bersalah, dan dimana Tuhan mengampuni semua dosa-dosa kita di atas dasar pekerjaan Yesus Kristus yang telah tergenapi." ${ }^{51}$ Dan kembali Sinclair Ferguson menyatakan bahwa: Didalam Firman Tuhan, membenarkan bukan berarti membuat benar seperti merubah karakter seseorang, membenarkan berarti menjadikan benar dengan cara mendeklarasikannya. ${ }^{52}$

Hal pembenaran dalam keyakinan soteriologi Kristen haruslah dimengerti dengan baik. William S. Plumer, dalam buku The Grace of Christ, mengatakan: Pembenaran adalah sebuah perbuatan. Pembenaran bukanlah pekerjaan, atau satu seri perbuatan. Pembenaran tidak progresif. Orang percaya yang paling lemah dan orang kudus yang paling kuat adalah serupa dan dibenarkan secara sama. Pembenaran tidak mengakui adanya tingkatan. Seseorang, hanya bisa seluruhnya dibenarkan atau seluruhnya dikutuk di hadapan Allah. ${ }^{53}$

Dengan demikian maka dalam keyakinan Kristen, seseorang diselamatkan bukan karena usahanya sendiri, melainkan karena pembenaran yang dilakukan Tuhan dalam kehidupannya, dan pembenaran tersebut merupakan anugerah Tuhan. Tentunya hal tersebut sesuai dengan pernyataan Alkitab bahwa: Sebab karena kasih karunia kamu diselamatkan oleh iman; itu bukan hasil usahamu, tetapi pemberian Allah, itu bukan hasil pekerjaanmu: jangan ada orang yang memegahkan diri. (Efesus 2:8-9). Hal inilah yang dilihat Luther ketika ia berhadapan dengan fakta indulgensia.

Ketika mempelajari doktrin soteriologi Kristen, maka setidaknya ada tiga teori soteriologi Kristen yang tidak bisa diabaikan,

${ }^{51}$ Anthony Hoekema, 178.

${ }^{52}$ Sinclair Ferguson, The Christian Life: A Doctrinal Introduction, 72.

${ }^{53}$ William S. Plumer, The Grace of Christ, (Philadelphia, PA: Presbyterian Board of Publication, 1853), 195. yaitu Universalisme Kristen, Calvinisme dan Armenianisme. Walaupun hingga kini ketiga hal tersebut masih ramai diperbincangkan dan bahkan cenderung diperdebatkan, namun pada kenyataannya menunjukkan bahwa soteriologi Kristen dapat ditinjau dari keempat sistem pola pikir teologi Kristen tersebut. Loraine Boettner seorang teolog Reformen dalam buku The Reformed of Doctrine of Predestination, mengatakan: There are really only there systems which claim to set forth a way of salvation through Christ. ${ }^{54}$ Bagi Boettner, ada sistem yang mengklaim dan menetapkan sebuah jalan keselamatan melalui Kristus.

\section{Universalisme Kristen}

Sebagaimana yang sudah diuraikan dalam bagian sebelumnya; menyatakan bahwa istilah universalisme, berasal dari kata bahasa Latin universum yang berarti alam semesta dunia, yang mana kata tersebut dikenal dalam bahasa Inggris sebagai universal. Kata yang dimaksudkan tersebut dapat berarti konsep umum yang dapat diterapkan pada sisi mana pun. Dari kata universalis dan universal itulah istilah universalisme berasal. Jadi Universalisme adalah paham yang percaya bahwa semua manusia pada akhirnya akan mendapat bagian pada keselamatan oleh Yesus Kristus.

Universalisme adalah ide pendapat yang universal, dan terdapat dalam beberapa kajian, diantaranya universalisme agama, politik, dan filsafat. Masing-masing memiliki tekanan dan kekhasannya sendirisendiri. universalisme agama adalah gagasan bahwa beberapa agama memiliki panggilan universal. Banyak yang percaya ini adalah nama dari visi ini bahwa gereja-gereja Kristen telah mengirim misionaris di seluruh dunia untuk mengkonversi orang. Kata

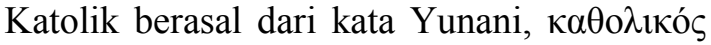
(katholikos), yang berarti universal.

\footnotetext{
${ }^{54}$ Loraine Boettner, The Reformed Doctrine of Predestination, (Phillipsburg, New Jersey: Prebyterian and Reformed Publishing Company, 1932), 47.
} 
Clement (150-215) atau Titus Flavius Clement merupakan salah seorang tokoh gereja Aleksandria yang terkenal dan juga dianggap sebagai seorang filsuf Kristen pertama. Ia dikenal karena usahanya dalam menyatukan filosofi Yunani dengan ajaranajaran Kristen dan karena usahanya itu maka ia berhasil menarik sejumlah besar penyembah berhala untuk menjadi Kristen. Minatnya terhadap filsafat, khususnya pada ajaran filsafat Plato, sangat berperan besar dalam upaya Clement menyebarkan ajaran Kristen di Yunani. Ia dianggap tidak ortodoks dan tokoh gereja yang kontroversial. Clement mengajarkan Injil dan doktrin Kristen kepada orang-orang yang akan baptis, mengundang orang-orang yang menyembah berhala dan petobat baru untuk mendengarkan ajarannya.

Kontribusi utama Clement bagi perkembangan doktrin gereja adalah usahanya untuk merekonsiliasi ajaran-ajaran Kristen dengan para filsuf Yunani kuno. Dia sendiri adalah sosok yang kompleks. Hal ini dapat dilihat saat ia menoleransi dan bahkan merangkul filosofi non-Kristen. Ini adalah sifat khas yang dimilikinya, bahwa dia hanya melihat permukaan dan ketidaksetujuan yang sifatnya sementara saja saat orang lain menemukan pertentangan yang mendasar. Clement bisa merekonsiliasi, dan bahkan menyatukan, pandangan-pandangan yang berbeda sampai kepada batas yang membuat upaya untuk menghubungkannya dengan sistem individual tertentu menjadi tidak mungkin dilakukan. Dia mengganti metode apologetik dengan metode konstruktif atau sistematik, mengubah tradisi gereja yang sederhana menjadi teologi dogmatik yang ilmiah.

Selain Clement, ada juga seorang lain yang bernama Origen (184-253) yang merupakan seorang cendikiawan Kristen yang sangat disegani. Ia dibimbing dalam asuhan beberapa filsuf kafir yang terkenal; salah satunya kepada filsuf Ammonius Sakkas yang terkenal sebagai pendiri NeoPlatonisme. Dengan demikian maka Origen menjadi seorang yang sepenuhnya menguasai filsafat Yunani.
Clement dan Origen memposisikan diri sebagai bagian dari keyakinan universalisme; sebagaimana diketahui bahwa universalisme adalah paham yang percaya bahwa semua manusia pada akhirnya akan mendapat bagian pada keselamatan oleh Yesus Kristus. Bagi pengikut universalisme, keselamatan yang didapatkan itu adalah anugerah Allah.

Kristen Universalisme adalah doktrin bahwa semua manusia; tanpa memandang agama mereka, akan diselamatkan. Paham ini diyakini oleh Gereja Universalis Amerika. Universalisme merupakan suatu pengajaran ada di hampir dengan semua agama yang ada, yaitu: suatu ajaran yang mempercayai bahwa semua manusia yang pernah hidup di dunia ini akan diselamatkan dan masuk ke dalam kerajaan sorga, apakah ia baik atau jahat semuanya akan ada di sorga karena Allah sangat mengasihi dunia dan orangorang berdosa. Universalisme adalah suatu doktrin yang mengajarkan bahwa pada akhirnya semua orang akan selamat, dan hal tersebut terjadi karena kasih karunia Tuhan atas seluruh umat manusia.

Secara tidak langsung, beberapa orang telah masuk dalam kelompok universalisme Kristen, diantaranya Hans Kung, Karl Rahner, Raimundo Panikkar, dan dari Indonesia adalah Victor I. Tanja dan sebagainya. Mereka mengakui bahwa, keselamatan hanya dapat diperoleh melalui Yesus Kristus tetapi dengan catatan bahwa Yesus Kristus itupun juga dapat hadir di luar tembok kekristenan. Sehingga sangatlah tidak bijak untuk membicarakan masalah hidup kekal dengan membedakan surga dan neraka. Alasan yang paling mendasar adalah karena Kristus itu kasih adanya sehingga tidaklah mungkin ada neraka atau tempat penghukuman yang kekal. ${ }^{55}$

Berkaitan dengan pengajaran universalisme Kristen, maka ada beberapa tinjauan yang dapat memberikan informasi mengenai keyakinan universalisme Kristen, yaitu:

\footnotetext{
${ }^{55}$ B. Kuyper, For Whom Did Christ Die? (Grand Rapids: Baker Book House, 1959), 13-14.
} 
Pertama, Uniersalisme Klasik, dimana universalisme versi lama yang mengajarkan bahwa semua para akhirnya akan diselamatkan karena Allah itu baik. Pandangan ini tidak banyak terdengar lagi sejak dari masa Origen (184-253) pada abad ke 3 sampai abad ke 19 di mana pandangan ini kembali bangkit, terutama oleh Gereja Universalis yang kemudian menyebarkan ajaran tersebut. Ada beberapa masalah dengan pandangan ini yaitu: ajaran Universalsiem Klasik merendahkan kepercayaan terhadap kematian Kristus yang menebus sebab jika semua dosa pada akhirnya akan diabaikan oleh kemurahan Allah, maka seharusnya Yesus Kristus tidak harus mati di Kayu Salib. Kematian-Nya bukan hanya tidak perlu bahkan merupakan suatu kesalahan terbesar dalam sejarah. Itulah sebabnya universalisme membutuhkan suatu pandangan tentang kematian Kristus untuk tujuan lainnya selain untuk penebusan dosa.

Kedua, Universalisme Baru yang muncul pada abad ke-20. Universalisme Baru melihat Alkitab secara lebih serius. Pandangan ini bersifat Trinitarian. Yesus Kristus memang mati bagi orang berdosa, dan semua pada akhirnya akan diselamatkan atas dasar penyediaan Kristus. Karl Barth (1886-1968) dan beberapa teolog dari NeoOrthodoksnya memegang pandangan seperti ini. Mereka percaya bahwa semua orang akan diselamatkan karena Allah itu mahakuasa. Tujuan Tuhan Allah adalah penebusan. Namun demikian, ada masalah dengan pandangan ini sebab jika semua pada akhirnya pasti diselamatkan, apa pun alasannya, maka pemberitaan Injil tidak perlu dilakukan. Juga hal hukuman Tuhan, dimana Alkitab mencatatnya bahwa penghukuman kekal (band. Lukas 16:19-31, Matius 7:13-14).

Walaupun keyakinan Universalsime Kristen yang menyatakan bahwa pada akhirnya semua orang diselamatkan dapat dibantah kebenarannya, namun fakta bahwa universalsime percaya bahwa semua manusia pada akhirnya akan mendapat bagian pada keselamatan oleh Yesus Kristus merupakan sebuah kenyataan.

Sebagaimana diungkapkan sebelumnya bahwa universalisme adalah kepercayaan bahwa setiap orang akan diselamatkan, dimana pemahaman ini telah begitu kuat masuk dalam kehidupan gereja Tuhan. Dalam perjalanan sejarah gereja, beberapa kelompok percaya pada pandangan keselamatan universal, dimana konsep bahwa semua orang pada akhirnya akan masuk Surga merupakan sesuatu yang dibanggakan. Pemikiran universalisme Kristen memberikan pengaruh buruk bagi teologi Kristen, khususnya berkaitan dengan konsep bahwa Yesus Kristus sebagai Tuhan dan Juruselamat manusia menjadi kabur. Pilihan keselamatan Kristen tidak lagi pada posisi yang kokoh mengenai Kristus, melainkan terdapat pilihan dimana agama-agama lainnya pun.

Universalisme Kristen telah salah memahami dan menginterpretasikan maksud dari penjelasan teologi Kristen, yang berkaitan dengan pengorbanan Kristus di kayu salib untuk menebus dosa umat manusia. Konsep yang universal dari kekristenan, namun terbatas itu, telah disalah mengertikan dan dianggap sebagai pengajaran universalisme. Jadi universalsime tetap percaya bahwa Yesus Kristus adalah juruselamat umat manusia.

\section{Soteriologi Calvinisme}

Teologi Reformasi yang dikumandangkan oleh Martin Luther (1483-1546) dapat disimpulkan dengan tiga ungkapan, yaitu: sola gratia, sola fide dan sola Scriptura. Dari ketiga ungkapan di atas terdapat makna teologis yang dalam, yaitu bahwa manusia hanya dapat diselamatkan oleh anugerah (gratia) Allah saja, dan bahwa manusia mendapat keselamatan itu dengan menyerahkan diri dalam iman (fides) kepada Yesus Kristus, serta kita dapat mengenal Allah dan kehendakNya hanya di dalam 
Alkitab (Scriptura) saja. ${ }^{56}$ Inilah yang mendasari teologi reformasi.

Dalam perkembangan selanjutnya, John Calvin (1509-1564) mampu memberikan rumusan yang lebih lengkap dari apa yang sudah disampaikan pendahulunya, Martin Luther dan teologi tersebut kemudian dikenal sebagai Calvinisme. Salah satu pokok penting dalam bahasan Soteriologi Kristen adalah ajaran Calvinisme yang hingga saat ini masih banyak pengikutnya. Kelompok ini sangat aktif berdiskusi dengan berbagai argumentasi historis dan theologis; ketika membahas isu-isu Soteriologi Kristen. Francois Wendel dalam buku Calvin, mengatakan: Calvinisme berbicara tentang mengenal Allah Alkitab dan hidup Coram Deo yaitu hidup di hadapan wajah Allah. Calvinisme sesungguhnya merupakan sinonim untuk Biblikalisme sistematis. Hanya Calvinisme yang memimpin kepada Kekristenan Alkitabiah yang sejati. Allah yang berdaulat adalah sentral dalam teologia Calvin. ${ }^{57}$ Jadi Wendel melihat Calvinisme sebagai sebuah ajaran yang biblikal dan sistematis sehingga mampu memimpin umat Kristen kepada pengertian theologi yang benar dimana Allah berdaulat atasnya.

Selain menyampaikan tema sentral tentang Kedaulatan Allah dalam warna teologinya, kaum Calvinisme juga menyampaikan pokok pemikiran Soteriologi yang tersusun dalam persidangan khusus untuk itu. Rangkuman theologi Calvinisme itu dikenal dengan istilah TULIP, dimana hal ini muncul sebagai reaksi atas kaum Arminianisme yang mempertanyakan doktrin keselamatan yang pada saat itu sangat populer dibicarakan.

Sejarah mencatat bagaimana kelompok Armenian menyampaikan bantahannya mengenai doktrin Predistinasi Calvinisme. Keduanya saling bersilang pendapat dengan argumentasinya masing-masing. Itulah sebabnya untuk memberikan jawaban dan sekaligus bantahan atas argumentasi

\footnotetext{
${ }^{56}$ Christian de Jonge, Apa itu Calvinisme?, (Jakarta: BPK Gunung Mulia, 2000), 45.

${ }^{57}$ Francois Wendel, Calvin, (Surabaya: Momentum,2010), 81.
}

kelompok Armenian tersebut maka kaum Calvinisme yang memandang pemikiran kelompok Arminianisme itu menyesatkan; akhirnya menyelenggarakan sebuah pertemuan yang khusus untuk membahas hal tersebut.

Persidangan khusus untuk hal yang membahas guna memberikan argumentasi atas kajian kelompok Armenianisme tersebut maka diselenggarakanlah sebuah persidangan, yaitu Sinode Dordrecht ${ }^{58}$ dan hasil keputusannya adalah menolak argumentasi Armenianisme. Perlu diketahui bahwa persidangan sinode yang dimaksudkan tersebut berlangsung pada tahun 1618$1619 .{ }^{59}$

Pemikiran Calvinisme sangat jelas, yaitu orang berdosa diselamatkan di dalam Kristus oleh Allah, dan pada saat diselamatkan yang dirasakan dan dialaminya adalah orang berdosa ini kini menerima anugerah Allah, Jadi keselamatan adalah Anugerah. ${ }^{60}$ Keselamatan bukan sesuatu yang dapat dikejar manusia dengan segala macam perbuatan, melainkan anugerah yang diberikan oleh Allah kepada manusia yang menyerahkan diri sepenuhnya kepadaNya. ${ }^{61}$

\footnotetext{
${ }^{58}$ Sinode Dordrecht diselenggarakan untuk menghadapi arminianisme, dan berlangsung pada tahun 1618-1619. Penyelenggaraan sinode Dordrecht dilatarbelakangi oleh pertikaian mengenai ajaran Arminius dengan kelompokkelompok politik Belanda yang mengarah pada pecahnya perang saudara. Untuk mengatasi hal tersebut, para pemimpin sinode se-Belanda dan juga dihadiri para utusan gereja-gereja Calvinis Inggris, Jerman dan Swiss untuk bertemu di Dordrecht, Belanda. Dalam sinode ini, dibahas pokok utama mengenai predestinasi yang dipertikaikan antara para remonstran dan kontraremonstran. Dalam akhir persidangan Sinode akhirnya pemikiran kaum remonstrasi, yang kemudian dikenal sebagai kaum Arminianisme ditolak dengan suara bulat dan selanjutnya sinode menyusun jawaban atas permasalahan tersebut dan keluarlah TULIP, yang merupakan inti pengajaran gereja-gereja Calvin.

${ }^{59}$ Tony Lane, Runtut Pijar, (Jakarta: BPK Gunung Mulia, 2005), 157-158

${ }^{60}$ G. J. Baan, Tulip, (Surabaya: Momentum 2009), 7.

${ }^{61}$ Christian de Jonge, Apa itu Calvinisme ?, 47.
} 
John Calvin adalah seorang reformator yang dikenal karena pemikirannya yang luar biasa bagi kemajuan reformasi gereja. William J. Bouwsma, dalam buku John Calvin: A Six Century Portrait, mengatakan bahwa: Calvin adalah seorang pemikir Kristen yang besar. Selain telah melahirkan apa yang disebut "Calvinism" ia juga seorang yang telahberusaha sungguh-sungguh untuk menyeberangkan "kebenaran Allah" keberbagai konteks kehidupan. Ia dan, kemudian, Calvinismenya diakui-sekaligus dikecam habis-habisan telah memberi karakteristik penting bagi perkembangan dunia modern. Ia telah mempengaruhi kapitalisme dan ilmu pengetahuan modern, disiplin dan rasionalisasi masyarakat Barat yangsangat kompleks, semangat revolusioner dan demokrasi, sekularisasi danaktivisme sosial, individualisme, utilitarianisme dan empirisisme. ${ }^{62}$

John Calvin merupakan salah satu tokoh penting dalam sejarah reformasi gereja. Lahir pada tanggal 10 Juli 1509 di kota Noyon, utara Prancis. Pada mulanya, orang tua Calvin menginginkan anaknya untuk menjadi imam di Gereja Katolik. Itulah sebabnya pada umur 12 tahun Calvin sudah menerima tonsur, yaitu pencukuran rambut dalam upacara inisiasi biarawan dan ia pada usia 18 tahun sudah menerima upah dari paroki St. Martin de Marteville. Dengan penghasilan tersebut Calvin dapat meneruskan pendidikannya pada jenjang yang lebih tinggi. pada tahun 1523 Calvin memasuki College de la Marche di Perancis. Di sini ia belajar retorika dan bahasa latin. Bahasa Latin dipelajarinya pada seorang ahli Bahasa Latin yang terkenal yaitu Marthurin Cordier (1479-1564). Kemudian ia pindah ke College de Montague. Di sini Calvin belajar filsafat dan teologi. Di sekolah inilah Calvin belajar bersama dengan Ignatius dari Loyola,

\footnotetext{
${ }^{62}$ William J. Bouwsma, John Calvin: A Six Century Portrait (New York-Oxford:Oxford University Press, 1989), 1.
}

yang kemudian hari menjadi musuh besar gerakan reformasi. ${ }^{63}$

Setelah Calvin menyelesaikan pendidikannya itu tiba-tiba ayahnya tidak menginginkan anaknya lagi untuk menjadi imam. Hal ini dikarenakan terjadinya perselisihan antara ayah Calvin dengan dengan keuskupan Noyon sehingga rencana semula dibatalkan. Ayahnya kemudian menginginkan Calvin untuk menjadi seorang ahli hukum. Oleh karena itu Calvin memasuki Universitas Orleans untuk belajar ilmu hukum. Kemudian ia juga belajar di Universitas Bourges dan Paris. Bahasa Yunani dan Ibrani dipelajarinya dari Melchior Wolmar (1497-1560), seorang ahli bahasa terkenal pada abad itu.

Dengan demikian Calvin menjadi seorang ahli hukum. Studi hukumnya sangat mempengaruhinya dalam usaha pembaharuan dan penataan gereja reformasi yang dipimpinnya di kemudian hari, dimana Calvin sangat menekankan ketertiban dan keteraturan dalam gereja. ${ }^{64}$

Pada tahun 1536 Calvin berangkat dari Basel ke Italia-Utara, di sana ia menginap beberapa waktu lama di istana permaisuri Ferrara, seorang wanita yang saleh, yang memberikan perlindungan kepada beberapa pemimpin gerakan reformasi gereja yang telah lari dari negerinya karena penganiayaan. Dalam perjalanan pulang ke Basel, ia sempat menginap semalam di Jenewa di Swiss; kemudian Willem Farel (1489-1565) mendengar bahwa Calvin berada di kota itu, maka dengan segera ia mencarinya, sebab nama dan kecakapan John Calvin yang muda itu sudah terkenal di kota tersebut. Farel sangat mendesak kepada Calvin supaya tinggal di Jenewa untuk membantu dia dalam pekerjaan Reformasi di sana, namun Calvin menolak permintaannya. Calvin tidak mau karena orang-orang Jenewa sudah terkenal suka mabuk, berjudi, berzinah dan seterus-

\footnotetext{
${ }^{63}$ F.D. Wellem, Riwayat Hidup Singkat TokohTokoh dalam Sejarah Gereja. (Jakarta : Gunung Mulia, 2000), 64-65.

${ }^{64}$ Ibid, 65.
} 
nya. ${ }^{65}$ Sementara Calvin adalah seorang pemalu dan penakut, sehingga dia tidak merasa layak untuk pekerjaan praktek. Tetapi Farel terus mendesak supaya ia tinggal di Jenewa dan tatkala Calvin tetap menolak namun karena terus didesak maka Calvin akhirnya bersedia tinggal di Jenewa. ${ }^{66}$ Kota Jenewa merupakan kota yang telah bebas dan otonom, pemerintahannya dipegang oleh dewan kota. Dewan ini tidak hanya mengurusi hal-hal politik tetapi juga mengambil alih tanggung jawab atas kehidupan gerejawi. Para imam besar diusir dari kota dan diangkat pendeta seperti Farel untuk membantu membenahi kehidupan gerejawi. ${ }^{67}$

Cikal bakal munculnya Calvinisme yang merupakan sebuah sistem teologi, khususnya Soteriologi; yang berisi pokokpokok pengajaran John Calvin, atau yang sering diientifikasikan dengan Lima Poin Calvinisme. Kelima pokok pemikiran tersebut diatas merupakan suatu ringkasan yang memberikan perbedaan antara Calvinisme dan Arminianisme. Walaupun bukan sebagai ringkasan lengkap dari tulisan Calvin atau keyakinan teologi gereja-gereja reformed pada umumnya, namun Lima Pokok Calvinisme menjadi acuan bagi banyak gereja dalam mempelajari keyakinan Calvinisme.

Ringkasan teologi Calvinisme tersusun dalam lima poin penting tersebut diatas, dikenal dengan sebutan TULIP, dan merupakan hasil rumusan persidangan Sinode Dorth. Istilah TULIP merujuk pada bunga khas Belanda dimana persidangan tersebut berlangsung. Poin-poin dalam TULIP sesungguhnya merupakan jawaban atas permasalahannya dengan kaum Armenisnisme. Poin-poin penting yang dimaksudkan itu adalah sebagai berikut:

Pertama, Total depravity atau Kerusakan total. Donald K. McKim, dalam

${ }^{65}$ Th. van den End. Harta dalam Bejana:

Sejarah Gereja Ringkas. (Jakarta :BPK. Gunung Mulia, 2003), 187

${ }^{66}$ H. Berkhof. Sejarah Gereja. (Jakarta : BPK.

Gunung Mulia, 2005), 159.

${ }^{67}$ Christiaan de Jonge, 8
The Westminster Dictionary of Theological Terms, mengatakan bahwa: "Total Depravity, merupakan Pandangan, dan karakteristik dalam theologi Reformed, dimana dosa telah meliputi semua bidang kehidupan atau totalitas eksistensi manusia." ${ }^{68}$ Ini terjadi sebagai akibat dari kejatuhan Adam seluruh umat manusia terpengaruh, semua manusia mati dalam pelanggaran dan dosa. Karena jatuh dalam dosa manusia mengalami kerusakan total. Kata total memiliki arti bahwa keadaan mati yang dialami manusia itu lengkap, sepenuhnya mati secara rohani. Manusia rusak secara total. Pengertiannya menjadi gelap sehingga tidak lagi mengenal Allah. Manusia tidak mampu untuk menyelamatkan dirinya sendiri. Kata rusak ini berarti kejatuhan di dalam dosa maka, tidak ada yang mampu dilakukan oleh manusia untuk menghasilkan jasa yang membuat Allah berkenan menyelamatkan mereka. Kata total mempunyai arti kerusakan yang sudah meluas sampai pada semua aspek dari natur manusia, sampai pada keseluruhan keberadaannya. ${ }^{69}$

Orang berdosa diselamatkan di dalam Kristus oleh Allah, dan pada saat diselamatkan yang dirasakan dan dialaminya adalah orang berdosa ini kini menerima anugerah Allah, Jadi keselamatan adalah anugerah. ${ }^{70}$ Keselamatan bukan sesuatu yang dapat dikejar manusia dengan segala macam perbuatan, melainkan anugerah yang diberikan oleh Allah kepada manusia yang menyerahkan diri sepenuhnya kepadaNya. ${ }^{71}$ Charles Hodge mengatakan: Kerusakan Total bukan berarti bahwa semua orang adalah jahat sehingga tidak mungkin menjadi seorang yang baik, atau seorang yang miskin moral sehingga tidak mungkin menjadi manusia yang jujur. Alkitab mengakui

\footnotetext{
${ }^{68}$ Donald K. McKim, The Westminster

Dictionary of Theological Terms, Second Edition: Revised and Expanded, (Kindle: Westminster John Knox Press, 2014), 213.

${ }^{69}$ Charles C. Ryrie, Total Depravity, ( Grand Raphids: Guardians, 1972), 9-13.

${ }^{70}$ G. J. Baan, Tulip, (Surabaya: Momentum 2009), 7.

${ }^{71}$ Jonge, Christian, 47.
} 
bahwa pada tingkat tertentu seseorang dapat saja menjadi baik, demawan dan berperilaku baik; bahkan orang kafir sekalipun. Para rasul mengajarkan bahwa mereka yang kurang standarnya tetap saja memiliki hati nurani sehingga bisa saja menjaga kekudusan hidup. Kesempurnaan hidup sebagai manusia yang benar harusnya dapat terlaksana. ${ }^{72}$

Walaupun orang yang sudah jatuh dalam dosa mampu secara eksternal melakukan perbuatan baik, mereka tidak dapat melakukan apa pun yang sesungguhnya baik, misalnya memperkenankan Allah (Rom. 8:8). Allah melihat hati. Dan berdasarkan sudut pandang-Nya, orang yang sudah jatuh dalam dosa tidak memiliki kebaikan, dalam pikiran, perkataan atau perbuatan. Oleh karena itu, ia tidak mampu memberikan sumbangsih apa pun pada keselamatannya.

Kedua, Unconditional election atau Pemilihan tanpa syarat yang mengantar Calvinisme kepada keyakinan akan kedaulatan Allah secara mutlak. Allah telah menetapkan dan mengetahui segala sesuatu sebelumnya, hal ini mencakup predestenasi. Pemilihan dan predestinasi adalah tanpa syarat. Oleh karena itu, pada saat Allah memilih manusia untuk keselamatan, Ia tidak memilih mereka berdasarkan pada apa pun yang ada pada diri mereka. Ia tidak memilih mereka karena kebaikan mereka sendiri, atau bahkan karena Allah mengetahui sebelumnya bahwa mereka akan percaya, melainkan hanya karena kemurahan-Nya semata-mata, yaitu berdasarkan anugerah (Efesus 2:8,9).

Ketiga, Limited atonement atau Penebusan terbatas. Agar diselamatkan manusia memerluan Juru selamat. Manusia tidak dapat mendapatkan keselamatan dengan mengorbankan binatang-binatang. Satu satu nya korban yang berkenan kepada Allah adalah korban yang memenuhi tiga tuntutan yaitu: benar-benar Allah, benar-benar manusia, benar-benar manusia yang benar, yaitu tanpa dosa. $^{73} \quad$ Dalam pemikiran

\footnotetext{
${ }^{72}$ Charles Hodge, Systematic Theology,

(Chicago: Moody Press, 2011), 425.

73 G. J. Baan, Tulip, 65
}

Calvinisme, seseorang ditebus karena anugerah Tuhan dan hal itu telah dilakukan dalam karya Yesus Kristus di kayu salib.

Keempat, Irresistible grace atau Anugerah yang tidak dapat ditolak. Mereka yang telah dipilih Allah dan Kristus telah mati bagi mereka, Allah menarik mereka pada diriNya melalui anugerah yang tidak dapat ditolak. Allah membuat manusia untuk datang ke pada Dia,. Pada waktu Allah memanggil, manusia menanggapi. Beberapa ayat yang digunakan untuk mendukung ajaran ini adalah Roma 9:16, Filipi 2: 12-13, Johanes 6: 28-29 dan Kisah Para Rasul 13:48 dan Yohanes 1: 12-13.

Kelima, Perseverance of the saints atau Ketekunan orang-orang kudus. Orangorang yang telah dipilih Allah dan ditarik kepadaNya melalui Roh Kudus akan dipelihara dalam iman. Tidak ada satupun dari orang yang sudah dipilih Allah akan terhilang, mereka pasti akan selamat secara kekal. ${ }^{74}$ Doktrin ketekunan ini diartikulasikan dalam Kanon Dort (Bab 5), yang Westminster Confession of Faith (Bab XVII), yang London Baptist Confession of 1689 (Bab 17), dan juga dapat ditemukan dalam Confessions Reformed lainnya.

Christian de Jonge dalam buku Apa itu Calvinisme? Mengatakan bahwa: "Akhirnya, pemerintah Belanda berinisiatif untuk mengumpulkan sinode se-Belanda, yang juga dihadiri oleh utusan-utusan sejumlah besar gereja Calvinis di Inggris, Jerman, dan Swiss untuk bertemu di Dordrecht." ${ }^{, 75}$ Dalam sinode ini, dibahas pokok utama mengenai predestinasi yang dipertikaikan antara para remonstran dan kontra-remonstran. ${ }^{76}$ Akhir persidangan sinode tersebut memutuskan untuk menolak pemikiran remonstar dengan suara bulat dan juga menyusun jawaban atas hal tersebut yang dikenal sebagai kanonkanon atau pasal-pasal Dort atau Lima Pasal

\footnotetext{
${ }^{74}$ Paul Enns, The Moody handbook of Theology, (Malang: Literatur SAAT, 2006), 109.

${ }^{75}$ Th. van den End. Enam Belas Dokumen Dasar Calvinisme. ( Jakarta: BPK Gunung Mulia, 2000), 57.

${ }^{76}$ Christian de Jonge, 122.
} 
melawan Remonstran. ${ }^{77}$ Di dalam Lima Pasal Dordrecht tersebut diuraikan bahwa keselamatan manusia hanya berlaku oleh rahmat Tuhan saja. ${ }^{78}$ Berdasarkan pokokpokok bahasan dalam Sinode Dordrecht, lahirlah apa yang dianggap dengan lima pokok Calvinisme, yang dikenal sebagai TULIP, sebagaimana yang diungkapkan dalam Lima Pokok Calvinisme. Sinode Dordrecht yang diadakan tahun 1618-1619 menjadi satu-satunya sinode Calvinis Oikumenis.

Sinode Dorth yang menghasilkan doktrin Calvinisme itu akhirnya menolak lima poin lingkasan pengajaran Arminianisme yang dianggap salah, dan bahkan mereka menuduh Arminianisme sebagai bidat yang mirip dengan semipelagianisme. $^{79} \quad$ Pelaksanaan Sinode Dordrecht dilatarbelakangi oleh pertikaian mengenai ajaran Jacobus Arminius (15601609) dengan kelompok-kelompok politik Belanda yang mengarah pada pecahnya

\footnotetext{
${ }^{77}$ Tony Lane, Runtut Pijar, 157-158.

${ }^{78}$ H. Berkhof. Sejarah Gereja, 212.

${ }^{79}$ Ajaran Pelagius yang ditolak oleh Gereja pada konsili di Kartago (418) dan Efesus (431); yang kemudian telah mempercepat munculnya ajaran Semi-Pelagianisme pada tahun 427-529. Adapun ajaran Semi- pelagianisme adalah: 1) Manusia memang mewarisi dosa dari Adam, tetapi dosa tidak membuat manusia mati, melainkan hanya sakit. Anugerah umum dari Allah menjadikan kehendak bebas manusia masih tetap bekerja. 2) Manusia butuh anugerah penebusan Kristus, barangsiapa percaya kepada Kristus akan diselamatkan. Manusia menerima atau menolak anugerah penebusan adalah murni kehendak bebas manusia, karena itu dalam keselamatan anugerah Allah dan kehendak bebas manusia saling bekerjasama (sinergisme). 3). Predestinasi bukan berdasarkan kedaulatan Allah tetapi berdasarkan prapengetahuan Allah. Dalam Sinode Orange (529) ajaran semipelagianisme ditolak oleh Gereja, namun demikian konsili Orange ini masih memiliki kemiripan dengan ajaran Semi- pelagianisme, sebab Konsili Orange menyatakan bahwa walaupun kehendak bebas manusia sudah sedemikian dilemahkan oleh dosa, namun masih masih tidak kehilangan kehendak bebasnya.
}

perang saudara karena pertentangan yang sedemikian hebat itu. ${ }^{80}$

Teologi Reformed sangat jelas membicarakan Soteriologi yang dikaitkan langsung dengan Yesus Kristus sebagai juruselamat umat manusia. jika memperhatikan Lima Pokok Calvinisme yang membicarakan tentang keselamatan, maka hal itu tidak lepas dari Yesus Kristus sebagai sentralisasi pembahasan Soteriologi kelompok ini. Keselamatan ada di dalam Kristus, tapi manusia yang telah jatuh dalam dosa dengan kesadaran sendiri tidak mungkin merespon datang kepada Kristus. Kemampuan untuk percaya kepada Kristuspun adalah anugerah dan pekerjaaan Rohkudus. Dengan demikian maka Calvinisme percaya bahwa Yesus Kristus adalah Tuhan dan Juruselamat umat manusia.

\section{Soteriologi Arminianisme}

Soteriologi Arminianisme dikenal sebagai bentuk dari pemikiran doktrin keselamatan Kristen yang berbeda dengan kayakinan soteriologi Kriten dalam pemikiran Calvinisme. Dapatlah dikatakan bahwa pemikiran teologi ini merupakan doktrin yang memberikan warna tersendiri setalah masa reformasi.

Keyakinan soteriologi yang tadinya dimonopoli oleh keyakinan Calvinisme; menjadi bertambah marak dengan lahirnya pemikiran soteriologi Arminianisme yang memberikan tekanan doktrinal dalam aspek yang sedikit berbeda dengan pemikiran Calvinisme.

Gereja Eropa yang masih hangat dengan peristiwa reformasi Martin Luther terus membenahi diri dalam banyak aspek, termasuk didalamnya berkaitan dengan doctrinal gereja.

Sebagaimana diketahui bahwa lahirnya gerakan reformasi di lingkungan gereja telah mendorong semangat dalam melakukan kajian teologis atas pokok-pokok pikiran dalam teologi Kristen. Pertikaian doktrinal dikalangan gereja reformasi para abad ke-17

\footnotetext{
${ }^{80}$ Tony Lane, $157-158$.
} 
sangat santer; terutama berkaitan dengan pengajaran John Calvin tentang Predistinasi. ${ }^{81}$ Jacobus Arminius (1560-1609) seorang teolog Belanda dengan tegas menolak pengajaran Calvinisme mengenai doktrin tersebut. Pemikiran kedaulatan Allah menjadi warna Calvinisme tidak diterima. Jacobus Arminius yang ketika itu menjabat sebagai profesor theologi di Leiden university dan juga gembala sidang gereja Dutch Reformed; berjuang untuk memodifikasi ajaran John Calvin tersebut. Arminius juga menentang ajaran teolog Belanda, Franciscus Gomarus (1563-1641) dan pengganti John Calvin, yaitu Theodore Beza (1519-1605).

Jacobus Arminius berbeda pendapat dengan pemahaman teologi yang diyakini kaum Calvinisme, khususnya tentang Predistinasi. Ia juga berusaha untuk memodifikasi Calvinisme sehingga Allah tidak dapat dianggap sebagai perancang, juga manusia sebagai robot ditangan Allah.

\footnotetext{
${ }^{81}$ Doktrin Predistinasi tidak hanya diajarkan oleh John Calvin melainkan juga oleh Agustinus, Wycliffe, Luther, Zwingli, Zanchius, Owen, Whitefield, Toplady, Bullinger, Bucer dan hampir semua tokoh dalam gerakan Reformasi. Selain ahli-ahli ahli teologi besar dalam sejarah tersebut, ajaran predestinasi ini juga diajarkan oleh tokohtokoh teologi modern seperti Hodge, Dabney, Cunningham, Smith, Shedd, Warfield, dan Kuyper. Dalam Pengakuan Iman Westminster Bab 3 butir 1 disebutkan tentang predestinasi bahwa "Allah pada mulanya, melalui kehendakNya yang bijaksana dan suci, dengan bebas (tanpa dipengaruhi apapun) dan pasti (tidak bisa berubah) telah menentukan segala sesuatu yang akan terjadi; sedemikian rupa sehingga Dia bukanlah pencipta dosa, dan tidak memaksakan kehendak mahluk ciptaanNya, serta tidak menghilangkan kebebasan dan keterlibatan pengaruh-pengaruh luar, melainkan memastikannya." Lebih jauh lagi dikatakan pada butir 2 bahwa "Meskipun Allah mengetahui segala sesuatu yang akan terjadi dalam segala kondisi; Dia tidak menentukannya karena Dia sudah melihat (mengetahui) hal-hal tersebut terlebih dahulu, atau karena Dia sudah mengetahui apa yang akan terjadi di masa mendatang apabila kondisi yang ditetapkan terlaksana."
}

Arminius yang pernah belajar belajar teologi di Universitas Leiden dengan para guru yang luar biasa, yaitu: Lambertus Danaeus (15301595), Johannes Drusius (1550 -1616), Guillaume Feuguereius , dan Johann Kolmann, yang merupakan teolog ternama pada waktu itu. Arminius juga sempat belajar di bawah bimbingan seorang teolog terkemuka lainnya yaitu Theodore Beza di Jenewa tahun 1582. Pada masa selanjutnya keduanya kemudian berbeda pendapat.

Johann Kolmann yang merupakan salah seorang guru Jacobus Arminius, memiliki keyakinan dan mengajarkan kepada para muridnya bahwa Calvinisme membuat Tuhan menjadi pribadi tiran dan algojo. Itulah sebabnya di bawah pengaruh para gurunya itu, Arminius belajar dengan baik dan memiliki bibit yang akan berkembang menjadi suatu teologi yang kemudian akan bersaing dengan teologi Reformed dari Yohanes Calvin. Arminius.

Para pengikut awal pengajaran Arminius di Belanda dikenal sebagai Remonstrants $^{82}$ setelah mereka menerbitkan dokumen berisi lima poin ketidaksepakatan dengan Calvinisme klasik, berjudul Remonstrantice (1610). Dalam usaha untuk mempertahankan Predestinasi Calvinis terhadap ajaran Dirk Volckertszoon Koornhert (1522-1590).

Arminius mulai meragukan aspek Calvinisme dan dengan demikian mengubah

\footnotetext{
${ }^{82}$ Remonstran berasal dari bahasa Latin remonstrare yang berarti menyatakan. Remonstran adalah rumusan pemahaman teologi Jacobus Armenius dan para pengikutnya. Dokumen Remonstran dirumuskan oleh J. Uitenbogaert, H. Grotius dan S. Episkopius pada tahun 1610. Isi dokumen itu adalah: 1) Pemilihan dan penolakan Allah (predestinasi) didasarkan sebelum iman (percaya), 2) Kematian Kristus adalah untuk semua orang, namun hanya orang percaya yang menikmatinya, 3) Manusia yang telah jatuh ke dalam dosa tidak dapat melakukan perbuatan baik. Mereka hanya mencapai keselamatan dengan pencurahan kuasa melalui roh kudus, 4) Rahmat Allah adalah permulaan dan akhir dari segala perbuatan baik, dan 5) Rahmat Allah dapat memelihara orang beriman dari setiap godaan.
} 
beberapa bagian pandangannya. Teologi Arminianisme tidak berkembang selama hidup Arminius, namun setelah kematiannya pada tahun 1609, Lima poin dalam Remonstrants yang disusun setahun setelah kematiannya merupakan formulasi dari ideidenya. Namun demikian Sinode Calvinis dari Dort yang bersidang menghasilkan keputusan untuk menolak dan bahkan mengutuk teologi Arminius tersebut. Kemudian melalui sinode Dort ini pun muncul rumusan Lima Pokok Calvinisme, dan mereka juga menganiaya para pendeta Arminian yang tinggal di Belanda. Namun meskipun sempat mengalami aniaya; Remonstrants terus berlanjut di Belanda sebagai gereja yang berbeda dan di mana Calvinisme diajarkan, di situ Arminianisme mengangkat kepala.

Jacobus Arminius menolak ajaran tentang anugerah yang tidak dapat ditolak atau Irresistible Grace, walaupun dia juga sepakat bahwa tidak seorang pun dapat berbalik kepada Allah tanpa anugerah Allah. Jika kaum Calvinisme percaya akan Predistinasi, maka kelompok Arminian menegaskan bahwa Allah membutuhkan kerja sama dari manusia, untuk mewujudkan keselamatan, di mana respons manusia merupakan faktor yang menentukan, agar keselamatan terealisasi. Paul Chulhong Kang, dalam buku Justification, menyatakan bahwa: Menurut Arminius rahmat ilahi adalah penting tetapi tidak merupakan suatu keadaan yang cukup untuk keselamatan, lebih spesifik lagi, bahwa Allah dengan anugerah pendahuluannya membuat manusia mampu untuk bekerja sama dengan kehendak ilahi di dalam keselamatan." 83

Teologi Arminian pada awalnya muncul dikalangan Protestan Calvinis Belanda yang mengikuti pandangan teologi Jacobus Arminius. Oleh karena itu mereka dikenal pula dengan nama kaum Arminian. Teologi Arminian sendiri baru dirumuskan setelah Jacobus Arminius meninggal dunia di tahun 1609. Dokumen yang dihasilkan oleh

\footnotetext{
${ }^{83}$ Paul Chulhong Kang, Justification, (New York: Peter Lang Publishing, 2006), 53.
}

para pengikut Arminius merupakan sebuah dokumen yang berisi pemikiran teologis dari kaum Armenian. Pada tahun 1610, Lima Poin Remonstrans ${ }^{84}$ diperkenalkan, dimana Inti dari Remonstrans Arminianisme terletak pada pernyataan bahwa martabat manusia menuntut adanya kehendak bebas. Oleh kalangan Calvinisme, pemahaman tersebut berarti menolak kasih karunia keselamatan dari Allah bahkan yang sebelumnya telah diterima. Ini artinya seseorang yang telah beriman kepada Kristus bisa menjadi murtad. Adapun kelima poin tersebut adalah:

Pertama, Kehendak Bebas; Pokok pertama dari Arminianisme adalah bahwa manusia memiliki kebebasan bertindak. Para Reformis mengetahui bahwa manusia mempunyai kehendak, dan disetujui dengan tesis Luther dalam bukunya yang berjudul Kehendak yang Terbelenggu yaitu tidak bebas dari belenggu Iblis. Arminius percaya bahwa kejatuhan manusia tidak berakibat rusak total, dan berpegang padakeyakinan tersebut itulah maka dianggap masih terdapat cukup kebaikan yang tersisa di dalam manusia untuk berkehendak menerima Kristus dan mendapat keselamatan.

Kedua, Pemilihan Bersyarat; Arminius mengajarkan bahwa pemilihan didasarkan pada pengetahuan Allah mengenai siapa yang akan percaya (foreknowledge). Dengan kata lain tindakan percaya manusia adalah syarat atau kondisi untuk pemilihan dirinya ke dalam kehidupan kekal, karena Allah melihat lebih dulu bahwa orang tersebut menggunakan kebebasan kehendak-nya dalam pewujudan yang positif terhadap Kristus.

Ketiga, Penebusan Universal; ketika semakin bertambah jauh keyakinan seseorang, yaitu: bahwa Allah mengasihi setiap orang, bahwa Kristus mati untuk setiap orang, dan bahwa Bapa tidak menghendaki setiap orang binasa, maka Arminius dan para pengikut menganggap bahwa pembebasan dosa atau redemption

\footnotetext{
${ }^{84}$ Duane Edward Spencer, TULIP: The Five Points of Calvinism in the Light of Scripture, (Grand Rapids, Michigan: Baker Book House, 2014), 4-5.
} 
digunakan secara tidak resmi sebagai sinonim untuk penebusan atau atonernen; adalah bersitat umum. Dengan kata lain bahwa kematian Kristus menjadi dasar atau alasan bagi Allah untuk menyelamatkan semua manusia. Meskipum demikian, masingmasing orang harus memanfaatkan kebebasan kehendak-nya untuk menerima Kristus.

Keempat, Anugerah dapat Ditolak; Para pengikut Arminius percaya bahwa karena Allah menginginkan semua manusia diselamatkan, maka Ia mengutus Roh Kudus mencari semua manusia supaya datang kepada Kristus. Meskipun demikian, karena manusia mempunyai kebebasan kehendak yang absolut, dan memiliki kemampuan untuk menolak atau menentang kehendak Allah bagi hidupnya. Meskipun pengikut Arminius mengatakan ia percaya bahwa Allah itu Mahakuasa, ia menegaskan bahwa kehendak Allah untuk menyelamatkan semua manusia dapat digagalkan oleh kehendak manusia yang terbatas yang ada pada tiaptiap individu.

Kelima, Hidup di luar Kasih Karunia; Pokok kelima dari Arminianisme merupakan hasil akhir yang logis dari bagian sistem yang terdahulu. Jika manusia tidak dapat diselamatkan oleh Allah kecuali kalau itu merupakan kehendak manusia untuk selamat, maka manusia tidak dapat terus menerus tinggal ata ada dalam keselamatan jika ia tidak terus menerus berkeinginan untuk selamat.

Para pengikut Jacobus Arminius itu telah berhasil menghasilkan dokumen yang memberi pengaruh bagi gereja hingga saat ini. Para perumus teologi Arminian diantaranya adalah: J. Uitenbogaert, H. Grotius dan S. Episkopius . Dokumen Remonstran yang terbit pada tahun 1610, berbentuk sebuah dokumen yang pada intinya menguraikan pokok-pokok pikiran teologi Arminian. Timo Pokki dalam America's Preacher And His Message, mengatakan: "Menurut Arminianisme, iman manusia tidaklah sebuah situasi dari fakta bahwa Allah memberi dan menawarkan keselamatan bagi laki-laki dan perempuan, tetapi hal ini adalah kondisi di mana seseorang harus bertemu, agar menerima keselamatan yang ditawarkan oleh Allah." $" 85$

Arminian mempunyai pandangan tersendiri mengenai keselamatan. Menurut Arminian, bahwa keselamatan dicapai melalui upaya gabungan dari Allah, yang mengambil inisiatif dan manusia, yang harus menanggapi respons manusia menjadi faktor yang menentukan. ${ }^{86}$ Benjamin Myers, dalam buku Milton's Theology of Freedom mengatakan bahwa menurut Arminian, mereka yang dipilih oleh Allah, karena mereka akan percaya kepada Allah. ${ }^{87}$

Pemilihan Allah atas mereka didasarkan kepada iman yang sudah dilihat, melalui pra-pengetahuan Allah, yaitu siapasiapa orang yang akan menerima dan percaya, maka berdasarkan hal itu, Allah memilih mereka, yang Allah sudah tahu sebelumnya akan percaya. Arminius mengajarkan bahwa pemilihan ialah berdasarkan kepada pra-pengetahuan Allah kepada siapa yang akan percaya. ${ }^{88}$ Mengenai konsep pilihan (election) Arminian tidak sependapat dengan Calvinis, di mana pemilihan itu tanpa syarat (unconditional election) bahwa Allah memiilih manusia untuk diselamatkan (Ef. $1: 3,4)$ dengan istilah yang populernya yaitu predestinasi. Predestinasi ialah menentukan terlebih dahulu. ${ }^{89}$ Robert A Peterson dan Michael D Williams, dalam buku Why I am not an Arminian, mengatakan: Para teolog Arminian telah memahami doktrin predestinasi dalam empat cara utama, masing-masing sesuai dengan pemahaman mereka tentang kebebasan manusia. Pertama,

\footnotetext{
${ }^{85}$ Timo Pokki, America's Preacher And His Message, (Boston:University Press of America:1999), 19.

${ }^{86}$ David N Steele and Gurtis C Thomas, The Five Points of Calvinism, (New Jersey:Presbyterian and Reformed Publishing Company,1963), 19.

${ }^{87}$ Benjamin Myers, Milton's Theology of

Freedom, (Berlin:Librabry of Congress,2006), 44.

${ }^{88}$ Annesah Nasheed, Made Simple Just Like God Planned it, (USA: AnnesahNasheed A.U.G. 2011), 287.

${ }^{89}$ Charles C. Ryrie, Teologi Dasar 2, 66.
} 
mereka menyatakan bahwa pemilihan dalam Alkitab adalah korporasi dan bukan individual. Kedua, penulis Arminian berpendapat bahwa berkaitan pemilihan kapan perorangan dalam Alkitab, hal tersebut berkaitan Allah memilih mereka untuk pelayanan, bukan keselamatan. Ketiga, Arminianisme telah menyatakan bahwa "pemilihan orang tertentu untuk menjadi anak-anak Allah dan ahli waris kehidupan kekal, adalah bergantung pada iman dan termasuk yang percaya. Keempat, seorang teolog Arminian mengajarkan bahwa pemilihan dalam Alkitab tidak ada hubungannya dengan takdir, melainkan adalah "predestinasi temporal" dan berhubungan hanya untuk hidup ini dan menjadi orang yang percaya itu ada hubungannya dengan preducision Tuhan untuk memberkati orangorang Kristen dengan berbagai cara. ${ }^{90}$ Arminianisme sebagai penerus dari pemikiran Yakobus Arminius, yaitu setelah kematiannya pada tahun 1609, meneruskan ajarannya, dengan menamakan diri sebagai kaum Remonstran yaitu suatu bentuk yang kontras dari pemikiran kaum Calvinis.

Bagi kaum Arminian pada dasarnya Allahlah yang memilih manusia yang diselamatkan, tetapi hal itu disebabkan oleh karena iman, yang sebelumnya kelihatan. Kaum Arminian dengan gamblang berkata, bahwa di dalam konsep pemilihan, Allah melihat iman dan siapa yang percaya dikemudian hari. Iman atau orang-orang yang percaya di masa yang akan datanglah menjadi faktor penentu dari pemilihan Allah. Martin Mulsow, dalam buku Socianism and Arminianism mengatakan: Arminius membedakan antara predestinasi dari pengelompokan orang-orang, yang mana hal itu bersyarat dan tidak bergantung dari prapengetahuan, dan pemilihan dari individuindividu, yang tak bersyarat dan bergantung terhadap pra-pengetahuan. Hal itu tentunya merupakan keadaan bahwa orang setia yang akan diselamatkan dan yang tidak setia

\footnotetext{
${ }^{90}$ Robert A Peterson and Michael D Williams, Why I am not an Arminian, (USA: Library of Congress Cataloging in Publicatiion Data 2004), 43.
}

dihukum, tetapi seorang individu hanya diselamatkan bergantung kondisi, prapengelihatan Allah, yang dipercayanya." $" 11$

Jadi, kaum Arminian menyebutkan bahwa ditentukannya sesorang untuk diselamatkan, bergantung akan prapengetahuan-Nya, di mana orang yang setia akan diselamatkan, dan orang yang tidak setia dihukum. Arminian melihat efektifitas panggilan akan terealisasi, jika manusia pada akhirnya mengungkapkan imannya kepada Allah. Pemahaman seperti ini mengedepankan, apa yang pada akhirnya manusia, bisa lakukan terhadap Allah, supaya Allah, kemudian bersedia menyelamatkan manusia.

Arminian juga percaya bahwa setelah orang menerima anugerah keselamatan maka seseorang juga dapat kehilangan keselamatan. Jack W. Cottrell, dalam buku Perspective on Election Five Views, mengatakan bahwa: "Falling from grace: those who believe and are truly saved can lose their salvation by failing to keep up their faith, etc." ${ }^{92}$ Cottrell menyatakan bahwa mereka yang percaya dan benar-benar diselamatkan dapat kehilangan keselamatan atau gagal menjaga iman mereka. Itulah sebabnya seorang Kristen harus terus berjuang untuk menjaga keselamatan yang diperolehnya.

Arminianisme di sisi lain mengajarkan bahwa keselamatan dapat diperoleh dan keselamatan itu sendiri juga bisa hilang di dalam hiduip orang percaya. Mereka juga percaya bahwa orang-orang dapat diselamatkan, namun sebagai akibatnya karena kekurangan pilihan mereka, mereka dapat kehilangan keselamatan mereka. ${ }^{93}$ Pertentangan dengan kaum Calvinisme termasuk dalam aspek ini. Calvin percaya akan doktrin predistinasi yang mana pilihan Allah tanpa salah pada diri seseorang dengan keselamatan yang pasti dan tidak akan hilang. Ajaran

\footnotetext{
${ }^{91}$ Martin Mulsow, Socianism and Arminianism (Netherlands:library of Congress Cataloging in Publication Data, 2005), 11.

${ }^{92}$ Jack W. Cottrell, Perspective on Election Five Views, (Nashville Tennessee:Holman Publishers, 2006), 18.

${ }^{93}$ Harding Hedgpeth, The Hope Of salvation, (USA:Lockman Foundation, 2008), 25.
} 
kelompok Armenianisme yang paling umum berkembang di gereja-gereja saat ini, meliputi: Kehendak Bebas atau kemampuan manusia, Pemilihan Bersyarat, Penebusan Universal atau pendamaian umum, Roh Kudus dapat secara efektif ditolak, dan Jatuh dari kasih karunia.

Dengan demikian, Arminius menolak dengan tegas pandangan John Calvin bahwa pemilihan terjadi tanpa syarat. Sesungguhnya Arminius tidak secara gamblang dan tegas menyatakan pandangan teologinya tersebut, mungkin untuk menghindarkan diri dari perselisihan dan perdebatan dengan kaum Calvinis yang kala itu memberikan reaksi yang cukup keras. Banyak tulisan dan karya Arminius baru diterbitkan setelah kematiannya. Tentunya hal ini berkat kerja keras para pengikut Arminianisme sehingga pokok-pokok pikiran Jacobus Arminius dapat ditelaah sebagai bagian dari pembelajaran sejarah oleh generasi masa kini.

Pemikiran Arminianisme merupakan sebuah pengajaran Soteriologi yang berbeda dengan ajaran John Calvin dalam kaitannya dengan konsep keselamatan dalam teolog Kristen. Dalam pemikiran Calvinisme, hal predistinasi merupakan sesuatu yang diagungkan dan menjadi andalan serta ciri khas Doktrin Reformed. Namun hal tersebut telah membuat Jacobus Arminius menolak pemikiran Calvin yang menyatakan bahwa Allah yang tanpa syarat memilih sebagian orang untuk diselamatkan. Bagi Arminius, pemilihan Allah adalah atas orang-orang yang percaya, berdasarkan pada iman. Tentunya pemikiran Arminius ini menjadi salah satu diskusi yang cukup hangat di kalangan teolog Belanda yang pada waktu itu. Ada banyak yang setuju dengan pemikiran tersebut, namun tidak sedikit yang menolak apa yang menjadi argumentasi Arminius tersebut. Pemikiran Arminius setidaknya telah memberikan pengaruh pada masyarakat Belanda kala itu, dan pemikirannya ini kemudian ditantang oleh
Franciscus Gomarus, kaum Calvinis Belanda. ${ }^{94}$

Kelompok Arminian yang menekankan bahwa Allah menentukan untuk memberi hanya tujuan dan bukanlah sarana. Bahwa Ia menentukan lebih dulu untuk mengaruniakan keselamatan kepada semua orang percaya, tetapi Allah tidak menetapkan orang-orang tertentu yang tidak percaya, yang kemudian menjadi percaya, serta berdiam dalam ketidakpercayaan mereka. Orang yang menerima Kristus melalui iman, melakukannya dengan pasti karena pilihan bebas dari mereka sendiri. Pilihan untuk percaya pada Yesus Kristus tidaklah ditetapkan. Pilihan semacam itu bagaimanapun juga adalah sudah diketahui sebelumnya, dan sebagai hasilnya seorang yang terpilih, menjadi pilihan, yang kemudian ditetapkan untuk menerima, berkat penuh keselamatan. ${ }^{95}$

Bagi Arminian, pilihan Allah kepada manusia, dipengaruhi secara langsung oleh iman berdasarkan kehendak bebas mereka. Jadi, mereka memberi penegasan, bahwa pilihan itu sudah diketahui sebelumnya. Robert A Peterson dapat dibagi dalam empat macam yaitu: Robert A Peterson, berkata di dalam bukunya Why I am not an Arminian, yaitu: Para teolog Arminian telah memahami doktrin predestinasi dalam empat cara utama, masing-masing sesuai dengan pemahaman mereka tentang kebebasan manusia. Pertama, mereka menyatakan bahwa pemilihan dalam Alkitab adalah korporasi dan bukan individual. Kedua, penulis Arminian berpendapat bahwa berkaitan pemilihan kapan perorangan dalam Alkitab, hal tersebut berkaitan Allah memilih mereka untuk pelayanan, bukan keselamatan. Ketiga, Arminianisme telah menyatakan bahwa

\footnotetext{
${ }^{94}$ Gomarus Franciscus (1563-1641) yang menjadi profesor teologi di Universitas Leiden, dan menjadi pemimpin ortodoks yang memberikan kristik tajam terhadap teologi Rwfoemasi, khususnya terhadap Arminius dan penggantinya Conradus Vorstius (1569-1622).

${ }^{95}$ Jack W Cottrell (ed), Perspective on Election Five Views, (Nashville Tennessee:Holman Publishers,2006), 81.
} 
"pemilihan orang tertentu untuk menjadi anak-anak Allah dan ahli waris kehidupan kekal, adalah bergantung pada iman dan termasuk yang percaya. Keempat, seorang teolog Arminian mengajarkan bahwa pemilihan dalam Alkitab tidak ada hubungannya dengan takdir, melainkan adalah "predestinasi temporal" dan berhubungan hanya untuk hidup ini dan menjadi orang yang percaya itu ada hubungannya dengan preducision Tuhan untuk memberkati orangorang Kristen dengan berbagai cara. ${ }^{96}$ Dari sini terlihat dengan jelas bahwa kaum Armeninisme memahami Doktrin Predestinasi berdasarkan apa yang mereka pahami. Tentunya hal tersebut kuranglah pas karena interpretasi suatu hal bukanlah berdasarkan pemandangan sendiri, melainkan upaya untuk memahami maksud dari penulis.

Paul Ens melalui buku, The Moody Handbook of Theology, memberikan pendapatnya tentang kaum Armenian, dengan mengatakan bahwa: "Kaum Arminian berpendapat bahwa, orang percaya dapat berpaling dari anugerah dan kehilangan keselamatannya. ${ }^{, 97}$ Dan mereka juga percaya bahwa penebusan Kristus hanya menghasilkan kemungkinan keselamatan. ${ }^{98}$ Miles J Stanfold berkata: Pilihan Allah atas individuindividu tertentu untuk keselamatan sebelum dasar dunia ini didasarkan pada sebelumnya mengetahui Nya bahwa mereka akan menanggapi panggilan-Nya. Dia memilih hanya mereka yang Ia tahu akan diri mereka sendiri dengan bebas percaya Injil. Oleh karena itu pemilihan ditentukan oleh atau dikondisikan pada apa yang manusia akan lakukan. Iman bahwa Allah melihat sebelumnya dan di mana Dia mendasarkan pilihan-Nya itu tidak diberikan kepada orang berdosa oleh Allah (hal itu tidak diciptakan

\footnotetext{
${ }^{96}$ Robert A Peterson \& Michael D Williams, Why I am not an Arminian, (USA: Library of Congress Cataloging in Publicatiion Data 2004), 43.

${ }^{97}$ Paul Enns, The Moody Handbook of Theology, 123.

${ }^{98}$ Ronald H Nash, Keselamatan di balik

Kematian Bayi, (Surabaya: Penerbit

Momentum, 2003), 73.
}

oleh kekuatan regenerasi Roh Kudus), tetapi hasil hanya dari kehendak manusia. Siapa yang akan percaya (dan karena itu yang akan dipilih untuk keselamatan) yang tersisa sepenuhnya terserah kepada manusia. ${ }^{99}$

Dengan demikian maka keyakinan Arminianisme berpijak pada usaha manusia dalam menentukan masa depannya berkaitan dengan keselamatan dari Allah. Keyakinan Arminianisme ini juga memberikan pernyataan bahwa keselamatan hanya dapat terwujud dari kehendak bebas manusia yang mau menerimanya. Jadi walaupun terdapat perbedaan yang cukup signifikan dengan pemikiran Calvinisme, dan walaupun terlihat perbedaan diantara keduanya begitu tajam, namun Arminianisme tetap percaya bahwa keselamatan hanya ada didalam Yesus Kristus.

\section{Tekanan Utama Soteriologi Kristen}

Para teolog Kristen telah melahirkan berbagai konsep Soteriologi Kristen dalam pandangannya masing-masing. Walaupun ada keragaman didalamnya, namun Soteriologi Kristen memiliki tekanan utama yang sama, yaitu: Yesus Kristus adalah Tuhan dan Juruselamat umat manusia.

Bagi kelompok Universalisme, mereka percaya akan kasih karunia Tuhan yang berlaku secara universal. Itulah sebabnya pada akhirnya semua orang akan diselamatkan oleh kasih karunia Allah dalam Kristus. Paul Enns, The Moody handbook of Theology mengatakan bahwa: "Teologi Calvinisme atau iman Reformed berakar pada tulisantulisan John Calvin. Khususnya yang diekspresikan dalam Institutes of the Christian religion. Teologia Calvin berpusat pada kedaulatan Allah." ${ }^{\text {100 }}$ Demikian juga dengan kelompok Armenianisme berpijak pada usaha manusia dalam menentukan masa depannya berkaitan dengan keselamatan dari Allah. Keyakinan Arminianisme ini juga memberikan pernyataan bahwa keselamatan

\footnotetext{
${ }^{99}$ Miles J. Stanfold, The Complete Green Letters, (Grand Rapids: Michigan1975), 316.

${ }^{100}$ Paul Enns, 108
} 
hanya dapat terwujud dari kehendak bebas manusia yang mau menerimanya. Selanjutnya Hyper Grace yang walaupun dianggap bermasalah dalam membangun teori karena mereka kurang tepat dalam menggunakan ayat-ayat Alkitab sebagai pendukung, dalam konteks dan penafsiran yang kurang tepap; namun sentralisasi Soteriologi mereka tertuju pada satu nama, yaitu Yesus Kristus.

Perbedaan paradigma dalam doktrin Soteriologi Kristen sebagaimana disebutkan diatas merupakan bentuk konsekuensi dari penerapan hermeneutika yang memberikan sudut pandang penafsiran terhadap suatu hal yang dibicarakan. Namun demikian, satu hal yang perlu digarisbawahi disini adalah; walaupun terdapat perbedaan sudut pandang dalam hal soteriologi Kristen, diantara kelompok Universalisme, Calvinisme, Arminianisme dan Hyper Grace; namun tetap menunjuk pada satu rujukan, yaitu keselamatan dari Allah dan dikerjakan dalam Kristus. Sesungguhnya Yesus Kristus adalah Tuhan dan juruselamat umat manusia; dan hal itu bersifat absolut.

Ketika ungkapan Alkitab yang dengan tegas menyatakan bahwa: "Dan keselamatan tidak ada di dalam siapapun juga selain di dalam Dia (Yesus), sebab di bawah kolong langit ini tidak ada nama lain yang diberikan kepada manusia yang olehnya kita dapat diselamatkan.” (Kisah Para Rasul 4:12). Demikian juga perkataan Yesus Kristus, bahwa: "Akulah jalan dan kebenaran dan hidup. Tidak ada seorangpun yang datang kepada Bapa, kalau tidak melalui Aku." (Yohanes 14:6); merupakan sesuatu hal yang mendasar dalam teologi Kristen dan hal itu tidak dibantah oleh keempat kelompok keyakinan soteriologi Kristen tersebut. Kesaksian bahwa Yesus Kristus adalah juruselamat umat manusia telah disampaikan oleh para nabi jauh sebelumnya; juga kesaksian Yesus Kristus sendiri dan kemudian disampaikan oleh para rasul.

Ajith Fernando, dalam buku Supermasih Kristus, mengutip Seorang teolog Jerman, Ernst Troeltsch ${ }^{101}$ dalam sebuah makalahnya, dia mengatakan bahwa kekristenan adalah absolut bagi orang kristen, sedangkan iman-iman lainnya adalah absolut bagi pengikutnya masing-masing. ${ }^{102}$ Ketika rasul Petrus menegaskan bahwa hanya Yesus juruselamat umat manusia (lih. Kisah Para Rasul 4:12), maka dengan tegas Petrus menyatakan bahwa Yesus adalah satusatunya jalan keselamatan (band. Yohanes 14:6; 1Yohanes 5:11-12). Signifikansi nama Yesus Kristus terus menjadi kultur sosioreligi yang terus dipercayai hingga kini.

Hendak ditegaskan dalam Kisah Para Rasul 4:12, yaitu pada saat Petrus menunjuk kepada nama Yesus Kristus; maka ia juga menegaskan bahwa tidak ada nama lain (selain Yesus Kristus) yang olehnya manusia diselamatkan. Perkataan Petrus ini menegaskan signifikansi nama Yesus yang menjadi sebuah pengakuan mendasar dari Iman Kristen bahwa "keselamatan hanya di dalam Yesus saja!" atau Solus Christus. Keberanian Petrus menyampaikan konsep Solus Christus didasari pada dua hal, yaitu:

Pertama, Nama Yesus berotoritas! Sebelum Petrus menyatakan pengakuan tersebut, sebuah peristiwa mendahuluinya, yaitu orang yang lumpuh disembuhkan dalam nama Yesus (lih. Kisah Para Rasul 3:6, 4:10). Jadi Petrus tidak saja menunjukkan otoritas nama Yesus atas penyakit jasmania, namun juga atas dosa manusia; dan dengannya mendatangkan pengampunan bagi yang mereka yang mau percaya (lih. Kisah Para rasul 2:38, 3:19; band. Matius1:21; Filipi 2:9-10). Bahkan di dalam nama Yesus, Iblis

\footnotetext{
101 Ernst Troeltsch (1865-1923), adalah teolog dan ahli filsafat Jerman yang sangat berpengaruh pada zamannya. Troeltsch menjadi profesor di Heidelberg dan Berlin. Ia merasa bahwa agama telah dipengaruhi oleh sosial budaya, dan menekankan kebebasan manusia dalam membentuk agamanya. Ernst Troeltsch sempat memasuki dunia politik dan dipilih menjadi Menteri Pendidikan dalam kabinet federal Jerman. Buku penting yang ditulisnya pada tahun 1923 adalah "Christian Thought and The Social Teachings of the Christian Churces". ${ }^{102}$ Ajith Fernando, Supermasih Kristus, (Surabaya: Penerbit Momentum, 2006), 88.
} 
pun tidak berkutik (lih. Kisah Para Rasul 19:17).

Kedua, Nama Yesus menyatakan pribadi, jati diri, dan reputasi-Nya. Pada saat rasul Petrus menyebutkan nama Tuhan Yesus, ia tidak sedang memperkenalkan sebuah nama, yang barangkali Yesus (bukan Yesus Kristus) juga dipergunakan oleh orang Yahudi lain pada masa itu. Rasul Petrus memakai nama Yesus yang berhubungan dengan pribadi, jati diri, dan reputasi-Nya yang telah dinubuatkan dan diberitakan para nabi dan bahkan telah menjadi saksi atas kebangkitanNya dari orang mati. Ada penggenapan janji Allah atas karya penebusan dosa manusia di Kayu Salib. Itulah sebabnya Petrus mengatakan, "keselamatan tidak ada di dalam siapapun juga selain di dalam Dia (Yesus)" (Kisah Para Rasul 4:12 bnd. Yohanes 14:6).

Arkhimandrit Daniel Bambang dalam buku Allah Tritunggal, menyatakan bahwa: "Iman Kristen percaya kepada Allah Tritunggal dan kepada Yesus Kristus, Sang Firman Allah yang datang dan keluar dari Allah sebagai penebus dosa-dosa dan juru selamat umat manusia." 103 G. C. Van Niftrik dan B. J. Boland berkata: Iman menjadikan kehidupan sebagai hidup manusia baru, sebagai manusia yang memandang dan taat kepada Yesus Kristus. Percaya berarti bahwa memandang kepada Kristus sebagai: 1) Nabi, yang di dalamnya firman Allah datang kepada kita, sehingga di dalam Dia telah dikatakan segalagalanya tentang yang harus diketahui manusia untuk dapat hidup dan untuk dapat mati, 2) sebagai Imam, yang satu kali untuk selamanya telah mempersembahkan diri-Nya, sehingga segala sesuatu telah Ia jadikan baik, dan akan Ia jadikan baik, 3) sebagai Raja, yang mempunyai kuasa memerintah dan juga mau melaksanakan kuasa mememrintah itu juga dalam hidup kita. ${ }^{104}$

\footnotetext{
${ }^{103}$ Arkhimandrit Daniel Bambang, Allah Tritunggal, (Jakarta: Satya Widya Graha, 2001), 15.

104 G. C. Van Niftrik dan B. J. Boland, Dogmatika Masa Kini, (Jakarta: BPK. Gunung Mulia, 1995), 333.
}

\section{Pembelajaran Pendidikan Agama Kristen}

Pendidikan adalah salah satu hal yang terpenting dalam kehidupan setiap manusia. Gagalnya pendidikan juga merupakan kegagalan kehidupan dan masa depan. Pendidikan merupakan usaha sadar untuk mendorong siswa mengalami peristiwa belajar di dalam hidupnya. Pendidikan sebagai usaha sadar manusia sebagai subyek, sebab manusialah pelaku pendidikan. Dalam hal ini tujuan pendidikan adalah membentuk manusia yang seutuhnya, membentuk pribadi yang mandiri dalam sifat pemikiran, perasaan, berwawasan luas dan mampu bekerja sama. ${ }^{105}$ Itulah sebabnya pendidikan menjadi sesuatu yang penting dalam kehidupan seseorang karena ia memberi dampak yang besar dalam kehidupan.

John Calvin mengatakan bahwa tujuan Pendidikan Agama Kristen adalah mendidik semua putra-putri gereja agar mereka terlibat dalam penelaahan Alkitab secara cerdas sebagaimana dengan bimbingan Roh kudus; mengambil bagian dalam kebaktian dan memahami keesaan gereja; diperlengkapi untuk memilih cara-cara mengejawantahkan pengabdian dirl kepada Allah Bapa dan Yesus Kristus dalam pekerjaan sehari-hari serta hidup bertanggungjawab dibawah kedaulatan Allah demi kemuliaan-Nya sebagai lambang ucapan syukur mereka yang dipilih dalam Yesus Kristus. ${ }^{106}$ Yesus Kristus harus menjadi pribadi sentral dalam dunia pendidikan Kristen, dan Alkitab harus menjadi dasar yang memberi inspirasi bagi setiap orang.

Homrighausen menyarikan tujuan Pendidikan Agama Kristen pada masa kini menjadi lima bagian utama. Tujuan tersebut adalah: Supaya mereka mengenal Allah sebagai pencipta dan pemerintah dunia ini, dan Yesus Kristus sebagai Penebus, Pemimpin dan penolong mereka; Supaya mereka mengerti kedudukan dan panggilan

\footnotetext{
${ }^{105}$ Hari Budiyana, Dasar-dasar Pendidikan Agama Kristen (Solo: Berita Hidup Seminary, 2011), 2.

${ }^{106}$ W. Stanley Heath, Teologi Pendidikan Anak (Bandung: Kalam Hidup, 2005), 414.
} 
mereka dan suka turut bekerja bagi perkembangan gereja di bumi; Supaya mereka mengasihi sesamanya karena Tuhan telah mengasihi mereka; Supaya mereka insaf akan dosanya dan selalu mau bertobat pula, Minta ampun dan pembaharuan hidup kepada Tuhan; Supaya mereka belajar terus mengenai berita Alkitab, suka mengambil bagian dalam kebak tianjemaat dan suka melayani Tuhan di segala lapangan hidup. ${ }^{107}$

\section{Penutup}

Walaupun doktrin Soteriologi Kristen terdiri atas beberapa kelompok dengan tekanan keyakinannya masing-masing, namun kesemuanya itu tidak mengabaikan peran Yesus Kristus sebagai juruselamat umat manusia.

Kelompok Universalisme Kristen yang percaya bahwa keselamatan itu bersifat universal; artinya pada akhirnya semua orang diselamatkan. Berbeda dengan universalisme agama ataupun keyakinan agama-agama dalam konteks pluralisme. Universalisme Kristen tetap menunjuk kepada Yesus Kristus sebagai jalan keselamatan bagi manusia.

Ketika kelompok Calvinisme yang menekankan aspek Kedaulatan Allah, sangat tegas menyatakan bahwa Yesus Kristus adalah juruselamat dunia; dan melaluiNya, setiap orang yang terpilih sejak masa kekekalan itu akan diselamatkan karena iman dan kepercayaannya akan Tuhan Yesus Kristus.

Kaum Armenianisme dengan tekanan Kehendak Bebas, dimana aspek manusia dipandang menentukan keselamatannya namun jalannya tetap ada didalam Yesus Kristus. Kelompok Armenianisme percaya bahwa manusia berkehendak bebas dan itu asalnya dari Tuhan, dan dalam kehendak bebas itulah maka seseorang terselamatkan karena ia percaya kepada Kristus.

Dengan demikian maka Soteriologi Kristen dengan berbagai kelompok

${ }^{107}$ E. G. Homrighausen \& I.H. Enklaar, Pendidikan Agama Kristen, 138. keyakinan karena pendekatan hermeneutika yang berbeda; telah melahirkan sejumlah teori dalam kajian doktri keselamatan. Tetapi pribadi Yesus Kristus sebagai satu-satunya jalan keselamatan bagi seluruh umat manusia, menjadi tekanan yang kuar didalamnya.

Jadi Soteriologi Kristen yang muncul sebagai bagian dari hasil kajian hermeneutika para ahli teologi, dapat memperkaya nuansa teologi seseorang, termasuk para guru yang terlibat dalam pembelajaran Pendidikan Agama Kristen. Studi teologi Soteriologi yang beragam tersebut tidalah perlu dipermasalahkan sebab intissari dari Soteriologi Kristen tidak digugat sama sekali. Keselamatan hanya ada dalam diri Yesus Kristus merupakan keputusan bersama dan final. Itulah sebabnya, pembelajaran Pendidikan Agama Kristen harus tetap berjalan sebagaimana mestinya. Ajaran bahwa keselamatan hanya melalui Yesus Kristus menjadi pokok dalam studi Soteriologi dan hal itu wajib dijabarkan dalam pembelajaran Pendidikan Agama Kristen.

\section{Daftar Pustaka}

Baan. G. J., Tulip, Surabaya: Momentum 2009.

Bambang. Daniel Arkhimandrit, Allah Tritunggal, Jakarta: Satya Widya Graha, 2001.

Becker. Dieter, Pedoman Dogmatika, Jakarta: Gunung Mulia, 1991.

Berkhof. Louis, The History of Christian Doctrines, Grand Rapids, Michigan: Wm.B.Eerdmans Publishing Company, 1953.

Berkhof. H., Sejarah Gereja. Jakarta : BPK. Gunung Mulia, 2005.

Boettner. Loraine, The Reformed Doctrine of Predestination, Phillipsburg, New Jersey: Prebyterian and Reformed Publishing Company, 1932. 
Bouwsma. J. William, John Calvin: A Six Century Portrait, New YorkOxford:Oxford University Press, 1989.

Boice. James Montgomery, Romans, Vol. I, Grand Rapids, MI: Baker Book House, 1991.

Cottrell. W. Jack, Perspective on Election Five Views, Nashville, Tennessee: Holman Publishers, 2006.

C. Groenen, Mariologi, Teologi dan Devosi, Yogyakarta: Penerbit Kanisius, 1994.

Ellis. Paul, Hyper Grace Gospel, Jakarta: Light Publishing, 2015.

Enns. Paul, The Moody handbook of Theology, Malang: Literatur SAAT, 2006.

Erickson. J. Millard, Christian Theology Jilid 3, Malang: Penerbit Gandumas, 2003.

Dister. Syukur Nico, Kristologi sebuah Sketsa, Yogyakarta: Penerbit Kanisius, 1994.

Fernando. Ajith, Supermasih Kristus, Surabaya: Penerbit Momentum, 2006.

Ferguson. Sinclair, The Christian Life: A Doctrinal Introduction, Carlisle, PA: The Banner of Truth Trust, 1989.

Graendorf. C. Werner, Introduktion to Biblical Christian Education, Chicago: Moody Press, 1988.

Grudem. Wayne, Systematic Theology: An Introduction to a Biblical Doctrine, Grand Rapid, Michigan: Zondervan Pub. House, 1994.

Heath. W. Stanley, Teologi Pendidikan Anak, Bandung: Kalam Hidup, 2005.

Hedgpeth. Harding, The Hope Of salvation, USA:Lockman Foundation, 2008

House. H. Wayne, Charts of Christian Theology and Doctrine, Michigan: Zondervan, 1992.

Hoekema. A. Anthony, Diselamatkan oleh Anugerah, Surabaya: Momentum 2006.

Hodge. Charles, Systematic Theology, Chicago: Moody Press, 2011.

Homrighausen. E. G., Pendidikan Agama Kristen, Jakarta: BPK Gunung Mulia, 1985.
Jonge. de Christian, Apa itu Calvinisme?, Jakarta: BPK Gunung Mulia, 2000.

Kang. Paul Chulhong, Justification, New York: Peter Lang Publishing, 2006.

Kristanto. Lilik Paulus, Prinsip dan Praktek PAK Penuntun bagi Mahasiswa Teologi dan PAK, Pelayan Gereja, Guru Agama dan keluarga Kristen, Yogyakarta : Andi Offset, 2009.

Kuyper. B, For Whom Did Christ Die? Grand Rapids: Baker Book House, 1959.

Lane. Tony, Runtut Pijar, Jakarta: BPK Gunung Mulia, 2005.

Marantika. Chris, Doktrin Keselamatan dan Kehidupan Rohani, Yogyakarta: Iman Press, 2002.

McGrath. E. Alister, Sejarah Pemikiran Reformasi, Jakarta: BPK. Gunung Mulia, 2002.

McKim. K. Donald, The Westminster Dictionary of Theological Terms, Second Edition: Revised and Expanded, Kindle: Westminster John Knox Press, 2014.

Mulsow. Martin, Socianism and Arminianism, Netherlands:library of Congress Cataloging in Publication Data, 2005.

Myers. Benjamin, Milton's Theology of Freedom, Berlin:Librabry of Congress, 2006.

Nainggolan. M. John, Guru Agama Kristen, Bandung: Bima Media Informasi, 2010.

Napel ten Henk, Kamus Teologi InggrisIndonesia, BPK Gunung Mulia, Jakarta 2011.

Nash. H. Ronald, Keselamatan di balik Kematian Bayi, Surabaya: Penerbit Momentum, 2003.

Nasheed. Annesah, Made Simple Just Like God Planned it, USA:AnnesahNasheed A.U.G. 2011.

Palmer. E. Richard, Interpratation Theory in Schleirmacher, Dilthey, Heidegger, and Gadamer, (terj. Hery dan Damanhuri M.), Yogyakarta: Pustaka Pelajar, 2005. 
Pazmino. W. Robert, Christian Education: Foundation for the Twent-first Century, Grand Rapids: Baker Academic, 2001.

Peterson. A. Robert and Michael D Williams, Why I am not an Arminian, USA: Library of Congress Cataloging in Publicatiion Data 2004.

Plumer. S. William, The Grace of Christ, Philadelphia, PA: Presbyterian Board of Publication, 1853.

Prince. Joseph, Unmerited Favor:Kemurahan yang Tidak Layak Diterima, Jakarta: Immanuel, 2014.

Pokki. Timo, America's Preacher And His Message, Boston:University Press of America, 1999.

Rahner. Hugo, Our Lady and the Church, Bethesda: Zaccheus Press, 1990.

Richardson. Alan, An Introduction To The Theology Of The New Testament, SCM Press LTD,London 1972.

Ryrie. C. Charles, Teologi Dasar 2, Yogyakarta: Penerbit Andi Offset, 1991.

Ryrie. C. Charles, Total Depravity, Grand Raphids: Guardians, 1972.

Ryrie. C. Charles, Basic Theology: A Popular Systematic Guide to Understanding Biblical Truth, Chicago: Moody Publishers, 1999.

Spencer. Duane Edward, TULIP: The Five Points of Calvinism in the Light of Scripture, Grand Rapids, Michigan: Baker Book House, 2014.

Sproul. R. C., Kebenaran-kebenaran Dasar Iman Kristen, Malang: Seminari Alkitab Asia Tenggara, 1997.

Stanfold. J. Miles, The Complete Green Letters, Grand Rapids: Michigan1975.

Steele. N. David and Gurtis C Thomas, The Five Points of Calvinism, New Jersey:Presbyterian and Reformed Publishing Company,1963.

Stevans. George Barker, The Christian Doctrine of Salvation, (New York: Charles Scribner's Sons, 1911.

Stott. R. W. John, Only One Way: The Message of Galatians, Downers Grove, IL: InterVarsity Press, 1968.
Sumiyatiningsih. Dien, Mengajar dengan Kreatif dan Menarik, Yogyakarta: Andi Offset, 2006.

Susabda. B. Yakub, Teologi Modern I, Surabaya: Lembaga Reformed Injili Indonesia, 1993.

Taylor. J. Marvin (ed), An Introduction to Christian Education, Nashville, New York: Abingdon Press, 1966.

Thomas. H. Groome, Christian Religious Education-Pendidikan Agama Kristen. Jakarta: BPK Gunung Mulia, 2010.

Th. van den End. Harta dalam Bejana : Sejarah Gereja Ringkas. Jakarta :BPK. Gunung Mulia, 2003.

Th. van den End. Enam Belas Dokumen Dasar Calvinisme. Jakarta: BPK Gunung Mulia, 2000.

Van Niftrik. G. C. dan B. J. Boland, Dogmatika Masa Kini, Jakarta: BPK. Gunung Mulia, 1995.

Wendel. Francois, Calvin, Surabaya: Momentum,2010.

Wellem. F. D., Riwayat Hidup Singkat Tokoh-Tokoh dalam Sejarah Gereja. Jakarta : Gunung Mulia, 2000.

Wuwungan. O. E. Ch., Pemahaman Alkitab dan Warga Gereja, Jakarta: Pustaka Sinar Harapan, 1997. 